\title{
Towards sustainable seawater desalting in the Gulf area
}

\author{
M.A. Darwish*, N.M. Al-Najemª ${ }^{\mathrm{a}}$ N. Lior ${ }^{\mathrm{b}}$ \\ ${ }^{a}$ Mechanical Engineering Department, Kuwait University, Kuwait \\ Tel.+965 498-5789; Fax+965 484-7131; email: darwish@kuniv.edu.kw \\ ${ }^{b}$ Department of Mechanical Engineering and Applied Mechanics, University of Pennsylvania, \\ Philadelphia, PA 19104-6315, USA
}

Received 26 November 2007; accepted revised 19 July 2008

\begin{abstract}
Gulf countries experienced rapid growth in the last four decades from oil production and its price increase. Natural water resources are very limited to meet this growth, and as result, desalted seawater in Kuwait became the main source of potable water, about $93 \%$ in 2002 . The electric power and desalted water, produced in co-generation power desalting plants (CPDP), consumptions are continuously increasing, almost doubled every 10 years, due to population and standard of living increases. This led to the consumption of huge amounts of fuel, draining the country main fuel (and income) resource, and negatively affecting the environment. One tenth of Kuwait's oil production was consumed by the CPDP in 2003. If the trend of almost doubling the consumption every 10 years prevails, the total oil production may not be sufficient to desalt seawater for people to drink, and to produce power to run space air conditioning units (a necessity for Kuwaiti harsh weather). It is essential therefore to look for energy efficient ways to produce power and desalted water so as to save the nation's income of these non-renewable fuel resources, to save the environment and indeed life itself in Kuwait, and this is the objective of this paper. It reviews the presently used desalting methods and their energy demand, and the correctness of fuel allocation formulas for CPDP, to determine the most efficient methods to apply and the less efficient ones to avoid. Fourteen desalting cases are analyzed by using the current practice, with and without combination with power generation plants (using steam or gas or combined gas/steam turbines cycles). The specific fuel energy consumed and the emitted $\mathrm{CO}_{2}, \mathrm{SO}_{\mathrm{x}}$, and $\mathrm{NO}_{\mathrm{x}}$ per $\mathrm{m}^{3}$ desalted water were calculated for each case. The results show that operating thermally driven desalting systems by steam directly supplied from fuel-fired boilers is the most inefficient practice, and should be avoided. The use of the gas/steam turbine combined cycle, which is also the most efficient powergeneration cycle, to drive seawater reverse osmosis (SWRO) desalination plants is the most efficient combination. Also, all conservation measures in utilization of both water and power should be applied. Reclamation of waste water, at least for non-potable water needs must be promoted, because it consumes less energy and at cost much lower than those of desalting seawater.

Keywords: Water desalination; Steam turbine power plants; Gas turbines power plants; Combined gas/steam power cycles; Dual purpose desalination plants; Energy consumption for water desalination; Sustainability; Air pollution; $\mathrm{CO}_{2}$ emissions
\end{abstract}

\footnotetext{
*Corresponding author.
} 


\section{Introduction}

Kuwait, like other Gulf countries, experienced very rapid growth in electric power and desalted water production in the last four decades due to the evolution of oil production and its price increase. One may ask, is this growth sustainable? The most used definition for sustainability [1] is the growth that meets the present generation needs without compromising future generations' ability to meet their own needs. Daly [2] stated that sustainability requires:

1. The use rate of renewable resources (e.g. groundwater) does not exceed the rate of their regeneration.

2. The use rate of non-renewable resources (e.g. fossil fuel, mineral ores) does not exceed the development rate of sustainable substitutes.

3 . The pollutants emission rate does not to exceed the capacity of the environment to absorb and render them harmless.

While most of the data used in this paper pertain to Kuwait, the general situation and trends of water and energy use and of their impact on resources and the environment are very similar in most of the Gulf countries. The renewable annual water resource (ground water) in Kuwait is less than $100 \mathrm{~m}^{3} /$ capita* (noting that annual $1000 \mathrm{~m}^{3}$ ) capita marks the water poverty line!), while the extraction (consumption) rate is more than $500 \mathrm{~m}^{3} /$ capita/y [5]. Over-extraction depletes the ground water and deteriorates its quality. While Kuwait has large amounts of fossil fuel oil, which can be used for producing new water, that resource has other major uses and is finite, with no practical alternative for its substitution.

\footnotetext{
* Water replenishment in Kuwait comes from rain to the Dammam limestone aquifers in the Um Ghadir field along the border of Saudi Arabia, and a very small percentage of the precipitation infiltrates into the groundwater in Kuwait $[3,4]$. The estimated renewable water is $75 \mathrm{~m}^{3} /$ (capita.y) [5], but the current extraction is about $510 \mathrm{~m}^{3} /($ capita $\cdot \mathrm{y})$.
}

Although full sustainability may not seem possible for the time being, efficient power and water production, alongside with much more modest consumption, are essential to allow the present resources to maintain the country's development over a longer time period, i.e., to make it more sustainable.

In Kuwait, about $93 \%$ of potable water need was secured by desalting seawater in 2002 [6]. Table 1 gives the installed capacity of desalting units and desalted water consumption in the last four decades. The daily-consumed fresh water in 1/capita increased from 137 in 1973 to almost 500 in 2003, and the population increased from 900,000 in 1983 to $2,540,000$ in 2003 , resulting in a 10-fold water consumption increased in $\mathrm{Ku}$ wait during that 30 -year period. This necessitated the production of large amounts of desalted seawater with respectively large fuel consumption for it.

The annual population growth, including both Kuwaiti and non-Kuwait residents, is estimated at $3.8 \%$, which more than double of the world average. Since water consumption obviously would increase with the population, it is noteworthy that in 1994 about $63 \%$ of the total populations were estimated to be non-Kuwaiti residents, pointing out that importation of foreign labor has an important effect on increasing the national water consumption.

Thermally operated desalting units usually obtain their heat input as steam supply; either extracted from steam turbines or from gas turbine exhaust heat recovery steam generators (HRSG) in combined cycle power generation systems (CC). Thus, the desalted water is produced generally in cogeneration power desalting plants (CPDP) sometimes also called dual-purpose plants.

Some desalination experts (cf. [7]) tend to underestimate the impact of the fuel consumed for desalting seawater on the environment, by considering that thermal desalination in CPDP is minimally responsible for flue gases discharged to at- 
mosphere as these discharges can be completely allocated to the power production. However, 22\% of the fuel consumed in Kuwaiti CPDP in 2003 was used for desalting as shown further below. The fuel consumed for desalting depends on the desalting method and the way energy is supplied to desalters. Burning fuel for desalting increases environment pollution by producing $\mathrm{CO}_{2}, \mathrm{NO}_{x}$, $\mathrm{SO}_{x}$, and other pollutants, with quantities directly related to the amount of fuel consumed. So, desalting clearly contributes to environmental pollution, including global warming. Increasing the efficiency of both power and desalted water productions thus lowers the impact of fuel combustion on the environment.

Tables 1 and 2 show that the consumed power and desalted water in Kuwait are almost doubled every 10 years. The oil production, (main source of income) was 1.983 million barrels/d (724 mil- lion barrels/y) in 2002, and little more than one tenth of this oil production (75.92 million barrels) was used in the CPDP in 2003. Following the same doubling trend and assuming a constant oil production rate, $20 \%$ and $40 \%$ of Kuwait total oil production (or total income) would be consumed by the CPDP in 2013 and 2023, respectively. Interpolating this trend (Fig. 1), in about thirty years the total oil production may not be sufficient for providing drinking water (mainly desalted water) and air-conditioning (using more than $75 \%$ of electric power consumption) in $\mathrm{Ku}-$ wait for its population if the present power and water consumption, and oil production, trends continue.

The water consumption in the years 1963, 1973, 1983, 1993, and 2003 were (Table 1) 5.5, 25.5, 86.2, 136.3, and 279.1 MIGD, respectively, an increase of $463.6 \%$ between 1963 and 1973,

Table 1

Installed desalting capacity and daily water consumption in Kuwait [6]

\begin{tabular}{lcccc}
\hline Year & $\begin{array}{l}\text { Installed capacity, } \\
\text { MIGD* }\end{array}$ & $\begin{array}{c}\text { Daily average consumption, } \\
\text { MIGD }\end{array}$ & \multicolumn{2}{c}{$\begin{array}{c}\text { Daily per capita fresh water consumption, } \\
\text { 1/d (IGD) }\end{array}$} \\
\hline 1963 & 6.0 & 5.5 & 82.8 & $(18.2)$ \\
1973 & 52.0 & 25.5 & 137.4 & $(30.2)$ \\
1983 & 136.0 & 86.2 & 245.0 & $(53.8)$ \\
1993 & 216.0 & 136.3 & 403.0 & $(88.6)$ \\
2003 & 313.5 & 279.1 & 497.3 & $(109.3)$ \\
\hline
\end{tabular}

${ }^{*} 1 \mathrm{IGD}=4.546 \mathrm{l} / \mathrm{d} ; 1 \mathrm{MIGD}=10^{6} \mathrm{IGD}=4,546 \mathrm{~m}^{3} / \mathrm{d}$

Table 2

Electric power production and consumption in Kuwait [6]

\begin{tabular}{|c|c|c|c|c|c|c|c|}
\hline Year & Population & $\begin{array}{l}\text { Installed power } \\
\text { capacity, MW }\end{array}$ & Million kWh & Max MW & Min MW & $\begin{array}{l}\text { Annual } \\
\mathrm{kWh} / \text { capita }\end{array}$ & $\begin{array}{l}\text { Max } \\
\text { load/capita kW }\end{array}$ \\
\hline 1953 & & 30 & & & & & \\
\hline 1963 & & 160 & 508 & & & 2,184 & \\
\hline 1973 & 900,965 & 1,096 & 4,183 & & & 4,643 & \\
\hline 1983 & $1,601,521$ & 3,866 & 12,499 & 2,740 & 5,00 & 6,747 & 1.711 \\
\hline 1993 & $1,537,714$ & 6,898 & 20,178 & 4,120 & 9,80 & 11,162 & 2.679 \\
\hline 2003 & $2,546,684$ & 9,189 & 38,577 & 7,480 & 2,110 & 12,992 & 2.938 \\
\hline
\end{tabular}




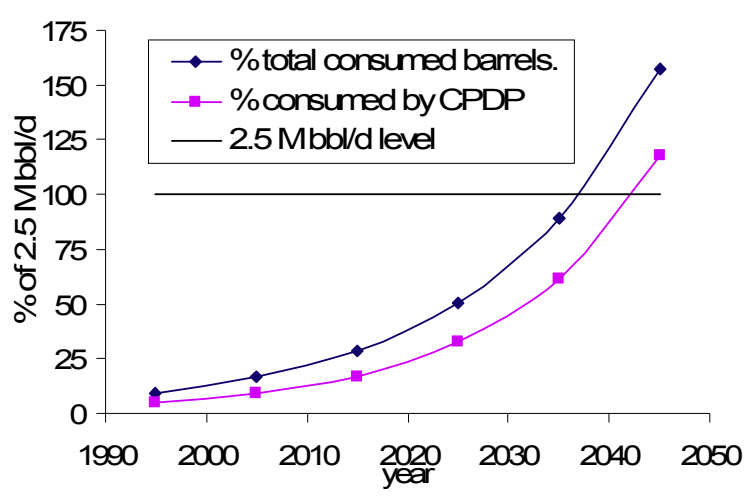

Fig. 1. Percentage of expected fuel consumption by all sectors and by CPDP, and their percentage of total sustainable fuel oil production of $2.5 \mathrm{M}-\mathrm{bbl} / \mathrm{d}$, for Kuwait.

$238 \%$ between 1973 and $1983,58 \%$ between 1983 and 1993, and 105\% between 1993 and 2003 .

The power consumption increase has paralleled that of the water consumption: in 1963, 1973, 1983, 1993, and 2003 it was (Table 2) 508, 4,183, $12,499,20,178$, and 38,577 million $\mathrm{kWh}$, respectively, an increase of $723 \%$ between 1963 and $1973,199 \%$ between 1973 and $1983,61 \%$ between 1983 and 1993, and 91\% between 1993 and 2003.

It is noteworthy that the power and water consumption almost more than doubles every 10 years except for the period between 1983 and 1993, when Iraq invaded Kuwait.

The 2004 Kuwait Ministry of Energy (ME) statistical book [6] reported that the consumed fuel energy in 2003 by the Kuwaiti power stations is 410,870 billion BTU $(433,491$ billion $\mathrm{kJ})$. If one barrel of oil produces $5.71 \mathrm{GJ}$ heat, then the fuel consumed is equivalent to 75.92 million barrels $/ y$. In 2003, Kuwait's oil production was 1.9825 million barrels/d or 724 million barrels/y, and the CPDP oil consumption is almost $10.4 \%$. While current predictions exist that the world oil may be depleted in about 40 years at the current rate of consumption [8], and though no definitive proof for that was given, there should serious concern about oil production depletion even if the oil supply may last much longer, and more efficient de- salting system as well as more modest rates of power and water consumption should be considered to save Kuwait's income, non-renewable fuel resources, environment, and indeed life itself.

An example of one of the possible solutions to the problem is the fact that the present Kuwaiti power plants' average efficiency is below $38 \%$, yet it can be improved in the future to $60 \%$ by employing combined gas/steam turbine cycles (CC). Also, the multi stage flash (MSF) desalting system consumes specific mechanical equivalent energy (containing both pumping energy of about $4 \mathrm{kWh} /\left(\mathrm{m}^{3} \text { desalted water }\right)^{*}$, and the heat supplied to both the brine heater and steam ejectors) in the range of $20 \mathrm{kWh} / \mathrm{m}^{3}$, but future use of reverse osmosis desalting systems (with energy recovery) can reduce this four-fold, to the range of $5 \mathrm{kWh} / \mathrm{m}^{3}$.

Furthermore, as described in more detail below, dealing with water as a free resource gives no incentive to utilize it efficiently and promotes un-sustainability.

As a first step in looking for efficient use of energy, this paper is devoted to review the present and possibly-used desalting methods and the way fuel energy passes through to supply the energy needs (either thermal, mechanical, or both) to desalters, and thereby to point out the most efficient systems to adopt, and the less efficient ones to avoid.

\section{Fuel consumed by desalting seawater in Kuwait in $\mathbf{2 0 0 3}$}

In 2003, the fuel energy consumed to produce electric power and desalted water in Kuwait was 433.5 million GJ (equivalent to 75.92 million barrels of crude oil based on 5.71 GJ energy content of one barrel). 431 million $\mathrm{m}^{3}$ desalted water and 35,577 million $\mathrm{kWh}$ electric power were produced [6]. The division of the used fuel between the pro-

\footnotetext{
* In this paper $\mathrm{m}^{3}$ always refers to the volume of desalted water
} 
duced power and desalination depends strongly on the allocation method (a general discussion is available in [9]), and the energy efficiency definition (cf. [10]). It is the authors' belief that the power generation efficiency for dual purpose plants, $\eta_{p 1}$, should be defined as

$\eta_{p 1} \equiv \frac{\text { net electric energy output }+ \text { electric energy loss due to thermal energy input to desalters }}{\text { energy of fuel consumed by the dual purpose plant steam generator }}$

This definition takes into account the fact that the desalination process consumes a lower quality (low temperature, pressure, and exergy) steam compared to that supplied by the steam generator of the CPDP. This gives an average power production efficiency $\eta_{p 1}=0.38$, (heat rate $=9,473 \mathrm{~kJ} / \mathrm{kWh}$ ), and thus the fuel charged to power is 337 million GJ (59 million barrels), and to desalted water it is 96.5 million GJ (16.92 million barrels). So, the average fuel energy charged to produce $1 \mathrm{~m}^{3}$ of water is $224 \mathrm{MJ} / \mathrm{m}^{3}$ (can be obtained by burning about $5 \mathrm{~kg}$ of fuel oil).

The estimated cost of fuel used to desalt seawater in 2003 , based on $\$ 60 /$ barrel, is 1015.2 million dollars. Moreover, the consumed fuel in 2003 for power and water added 33,780 tons of $\mathrm{CO}_{2}$ to the environment.

It is interesting to compare these numbers with those published by the Kuwait Ministry of Energy (ME) report [6], in which the efficiency of power production is defined as

$\eta_{p 2} \equiv \frac{\text { power output }}{\text { fuel energy consumed by the dual purpose plant steam generator }- \text { thermal energy to desalting }}$

with reported $\eta_{p 2}=42 \%, 10.5 \%$ higher than $\eta_{p 1}$. This definition implicitly but erroneously assumes that the desalination process is charged with fuel energy equal to the heat supplied to the desalters, and charged the balance from the total fuel energy input to the power process. In fact the fuel energy is used to generate steam which is used in producing both power from the turbine and thermal energy to the desalters. The logic of Eq. (1) is to find the equivalent work of the thermal energy supplied to the desalters, and added to the power output to get the CPDP total output in terms of work. It is obvious (cf. [10]) that Eq.(1) is more rational to use than Eq. (2) which charges the desalination process as if it is operated directly from fuel fired boilers.

Using that definition, the cost of $433.491 \times 10^{6}$ GJ (75.92 million barrels) was reported in [6] to be 1,542.4 million dollars, or $\$ 20.32 /$ barrel, which is rather low relative to international oil market prices of more than $60 \$ /$ barrel.

\section{A forecast and plan for action}

Observing past trends of energy consumption in Kuwait, including the energy used for desalination, it is of great interest to foresee the ability of Kuwait to supply its overall energy and desalination needs if those trends are not changed. Table 3 shows the energy consumption trends, by energy sector, in the period 1995-2005, clearly demonstrating exponential growth.

The estimated oil reserves suggest that the sustainable fuel oil production rate in Kuwait is 2.5 M-bbl/d over a 100 years period. Based on the last 10 years trend of the fuel consumption, the estimated future consumption is given in Fig. 1 and Table 4. These show that the end fuel consumption will reach the whole oil production in the year of 2037. Moreover the consumption by the CPDP only can reach the end fuel production rate by the year 2043. To preserve the ability of the next generations, and in fact even of the present 
Table 3

Kuwait's local consumption of energy in the main sectors (in thousands barrels) (The Kuwait Ministry of Energy (ME) website http://www.moo.gov.kw

\begin{tabular}{|c|c|c|c|c|c|c|c|c|c|c|c|}
\hline & 1995 & 1996 & 1997 & 1998 & 1999 & 2000 & 2001 & 2002 & 2003 & 2004 & 2005 \\
\hline $\begin{array}{l}\text { Electricity } \\
\text { general sector }\end{array}$ & 42,943 & 46,771 & 49,009 & 55,123 & 58,042 & 60,254 & 63,903 & 68,130 & 70,669 & 75,684 & 81,689 \\
\hline Oil sector & 25,187 & 24,096 & 27,140 & 30,410 & 32,520 & 29,450 & 32,396 & 33,708 & 38,439 & 44,059 & 41,354 \\
\hline $\begin{array}{l}\text { Transportation } \\
\text { sector }\end{array}$ & 16,004 & 16,693 & 17,422 & 17,781 & 18,113 & 18,182 & 18,953 & 20,174 & 21,974 & 23,703 & 25,382 \\
\hline $\begin{array}{l}\text { Household } \\
\text { sector }\end{array}$ & 1,100 & 1,110 & 1,153 & 1,147 & 1,173 & 1,184 & 1,218 & 1,281 & 1,325 & 1,340 & 1,550 \\
\hline Total & 85,234 & 88,670 & 94,724 & 104,461 & 109,848 & 109,070 & 116,470 & 123,293 & 132,407 & 144,786 & 149,975 \\
\hline
\end{tabular}

Table 4

Forecasted fuel consumption in thousands of barrels per year by all sectors and by CPDP, and their percentage of total sustainable fuel oil production of $2.5 \mathrm{M}-\mathrm{bbl} / \mathrm{d}$ for Kuwait (basic data from [6], further analysis by authors)

\begin{tabular}{lcccc}
\hline Year & \multicolumn{2}{l}{ Total oil consumption (all sectors) } & \multicolumn{2}{c}{ Total oil consumption (CPDP sector) } \\
\cline { 2 - 4 } & Barrels (in 1000s) & $\begin{array}{l}\text { Percentage of total oil } \\
\text { production }\end{array}$ & Barrels (in 1000s) & $\begin{array}{l}\text { Percentage of total } \\
\text { oil production }\end{array}$ \\
\hline 1995 & 85,234 & 9.34 & 42,924 & 4.70 \\
2005 & 149,945 & 16.43 & 81,689 & 8.95 \\
2015 & 263,786 & 28.91 & 155,463 & 17.04 \\
2025 & 464,056 & 50.86 & 295,863 & 32.42 \\
2035 & 816,374 & 89.47 & 563,059 & 61.71 \\
2045 & $1,436,179$ & 157.39 & $1,071,562$ & 117.43 \\
\hline
\end{tabular}

one, to sustain a satisfactory lifestyle, it is obvious therefore that Kuwait, and most other Gulf countries dependant on water desalination, must rapidly start action to drastically reduce the rate of energy consumption in general and the demand for energy consuming products, with water in particular.

The remainder of this paper focuses on a comparison of energy consumption and emissions of fourteen prevailing desalination processes, to point out their sustainability in view of this situation and forecast.

\section{Energy rating methods of desalting processes}

The desalination industry uses a number of different energy performance criteria, which be- sides preventing uniformity, also tend to misrepresent rational evaluation, and especially fuel cost allocation to the produced water when dual-purpose (power and water) plants are employed. The gain ratio (GR) and the performance ratio (PR) are the two most commonly applied methods for rating thermal driven desalting systems, such as the thermal vapor compression TVC, multi stage flash MSF, and multi effect boiling MED desalting units.

The GR is the desalted water output $(D)$ per $\mathrm{kg}$ of supplied heating steam $(S)$ defined by $\mathrm{GR}=D / S$. The GR does not consider the actual heat quantity given by each $\mathrm{kg}$ of used steam, $\Delta h$ (the enthalpy difference across the desalination plant heater), or the actual heat consumed by the desalter. It is more logical is to calculate the heat 
required $Q_{d}$ per unit mass of desalted water $D$, i.e., $Q_{\delta} D$, instead. This was taken into consideration by defining another energy rating parameter, the performance ratio (PR), by changing the $S$ used in the definition of GR to the associated amount of heat $Q_{d}$ based on the standard value of the latent heat of evaporation of water, $\Delta h_{\text {ref }}$ $=2,330 \mathrm{~kJ} / \mathrm{kg}$ (for example, if the supplied steam enters as saturated vapor and leaves as saturated liquid, at about $70^{\circ} \mathrm{C}$, which is the average temperature of operating thermally driven desalting system), and thereby PR is the desalted water output $D$ per kg of supplied steam that has the reference latent heat value $\Delta h_{\text {ref }}=2,330 \mathrm{~kJ} / \mathrm{kg}$, and then $\mathrm{PR}=\mathrm{GR}$.

Both the GR and PR are deficient in that they do not take into consideration the pressure, temperature and quality of the specifically used steam, or the pumping energy consumed by the process. The real value of steam lies in its ability to produce work (its exergy), which increases with both temperature and pressure. A modified performance ratio, $\mathrm{PR}^{\prime}$, which takes the real amount of heat used by the plant, $Q_{d}=S \Delta h$, defined by the actual enthalpy drop $\Delta h$ of the steam in the brine heater would thus be $\mathrm{PR}^{\prime}=\mathrm{PRH}(\Delta h / 2330)$.

This distinction is especially important when evaluating TVC units, which usually use high pressure (and exergy) steam (say at 10-20 bar) compared to the well known multi stage flash MSF and multi effect ME desalting system, and the GR or PR rating, which overlook this fact introduces a significant error.

Obviously the best way to evaluate the performance of any desalting system is to account for the actual total fuel energy required (consumed) including the heat and work,, to desalt a unit mass or volume of desalted water, $\left(Q_{f} / D\right)$, say in $\mathrm{MJ} / \mathrm{m}^{3}$, $\mathrm{kJ} / \mathrm{kg}$, or $\mathrm{kg}$ fuel $/ \mathrm{m}^{3}$ of desalted water, where the work is calculated in terms of the fuel needed to generate it in say a power plant of 0.36 standard efficiency or by using its exergy value. The same logic was used in a previous desalination sustainability indicators study [11]. The first indicator is the resource fuel, defined by amount of fuel in $\mathrm{kg}$ per $\mathrm{m}^{3}$ of desalted water.

Other energy-related sustainability indicators include environmental ones, including the amount of polluting gases emitted during the combustion of the fuel needed for producing one $\mathrm{m}^{3}$ of desalted water, such as $\mathrm{kg} \mathrm{CO}_{2} / \mathrm{m}^{3}, \mathrm{~kg} \mathrm{SO} / \mathrm{m}^{3}$, and $\mathrm{NO}_{\mathrm{x}} / \mathrm{m}^{3}$.

\section{Water desalination in the Gulf area}

The renewable water resources in many Middle East counties, especially the Arab Gulf countries, are highly insufficient to satisfy their water needs, and desalination supplies the large shortfall. Table 5 gives the renewable water resource (mostly groundwater) and the percentage of its extraction (and thus consumption), total and per capita of installed desalting capacity for year 2004. The capacity of the MSF and SWRO desalting units installed in the last 10 years are given for countries, where desalted waters are used extensively. The trend of shifting from complete dependence on the MSF systems, to the more efficient SWRO system is clear in the last decade as shown in Table 6 [5].

\section{Water consumption inflation}

The fresh water consumption in Kuwait, of more than $500 \mathrm{l} /$ capita/d (Table 1), is much higher than even in the most developed countries in the world. The potable water consumption per capita per day in USA, Australia, and Canada is in the range of $250 \mathrm{l} / \mathrm{capita} / \mathrm{d}$; in Denmark and France is in the range of $1801 / \mathrm{capita} / \mathrm{d}$, and in Germany, Belgium, and Portugal is in the range of $140 \mathrm{l} / \mathrm{capita} / \mathrm{d}$ [12]. In these countries, the consumed water is related to the water price, which is $\$ 0.41 / \mathrm{m}^{3}$ in Canada, $\$ 0.5 / \mathrm{m}^{3}$ in USA, $\$ 1.17 / \mathrm{m}^{3}$ in France, and $\$ 1.81 / \mathrm{m}^{3}$ in Germany [12]. In Kuwait, the data from [6] shows that the amount of fresh water consumed in 2003 was $463.1 \times 10^{6} \mathrm{~m}^{3}$, and the ME income from selling that water was $\$ 75.816 \times 10^{6}$, 
Table 5

Renewable water resources in some Arab countries, 2004 [6]

\begin{tabular}{lclccc}
\hline Country & $\begin{array}{l}\text { Annual renewable } \\
\text { source } \\
\left(\mathrm{m}^{3} / \text { capita }\right)\end{array}$ & $\begin{array}{l}\text { Annual extraction } \\
\text { of renewable water } \\
(\%)\end{array}$ & $\begin{array}{l}\text { Total installed } \\
\text { desalination } \\
\text { capacity }\left(\mathrm{m}^{3} / \mathrm{d}\right)\end{array}$ & $\begin{array}{l}\text { Desalination installed } \\
\text { capacity/capita } \\
(1 / \text { capita })\end{array}$ & $\begin{array}{l}\text { \% of the world } \\
\text { MSF capacity }\end{array}$ \\
\hline Bahrain & & & 516,059 & 792.7 \\
Egypt & 923 & 97 & 303,915 & 4.7 & \\
Iraq & 5,340 & 43 & 397,753 & 16.7 & 12.0 \\
Jordan & 314 & 32 & 328,507 & 65.3 & \\
Kuwait & 100 & 510 & $2,181,026$ & $1,067.0$ & 158.9 \\
Libya & 111 & 767 & 859,514 & 136.6 & 29.9 \\
Oman & 892 & 24 & 334,879 & $1,276.0$ & 31.0 \\
Qatar & & & 762,932 & 307.0 & \\
KSA & 254 & 164 & $6,569,172$ & $1,586.0$ & \\
UAE & 1,047 & 299 & $5,532,777$ & & \\
\hline
\end{tabular}

Table 6

Capacities of seawater MSF and SWRO desalination units operated in some Arab countries since 1994 [6]

\begin{tabular}{lrr}
\hline Counties & \multicolumn{2}{c}{ Capacities $\left(\mathrm{m}^{3} / \mathrm{d}\right)$} \\
\cline { 2 - 3 } & \multicolumn{1}{c}{ MSF } & \multicolumn{1}{c}{ SWRO } \\
\hline Bahrain & 136,200 & 3,600 \\
Kuwait & 336,104 & \\
Libya & 44,240 & \\
Oman & 194,982 & 2400 \\
Qatar & 334,640 & \\
KSA & $1,337,508$ & 475,516 \\
UAE & $2,522,109$ & $2,518,650$ \\
\hline
\end{tabular}

which gives a price of $\$ 0.1637 / \mathrm{m}^{3}$. This is $2.5-11$ fold less than the cost in the above listed countries, which are also by many orders of magnitude more water-rich. This low price is a major reason for the extremely high rate of water consumption in Kuwait and shows that water is apparently treated by some as a free common resource with almost zero economic value. The under-valuation is in fact even much worse, because as mentioned above, the fuel energy consumed for desalting is $224 \mathrm{MJ} / \mathrm{m}^{3}$, resulting in a fuel cost for desalination of $\$ 1.57 / \mathrm{m}^{3}$ produced fresh water when considering an oil price of $\$ 40 /$ barrel
(\$7/GJ) and \$3.14 for the current oil prices reaching $\$ 80 /$ barrel. The fuel cost to produce $1 \mathrm{~m}^{3}$ of desalted water is $\$ 2.35$ for a barrel cost of $\$ 60$ / barrel. If the total water cost is twice that of the fuel, then it is $\$ 4.71 / \mathrm{m}^{3}$, or 28 times the selling price of $\$ 0.1637 / \mathrm{m}^{3}$. Since the total cost of desalted water includes the capital and other operation expenses, the actual cost allocated to the water may be at least two-fold higher. This would be about twenty to thirty times higher than the price charged to the customers! Furthermore, the high amount of fuel consumed for producing power and water leads to environmental damage and degrades natural resources, all of which should be also considered in the determination of the price of the water, and may lead to unsustainable economic development.

The present water production rate in Kuwait can meet water needs for many years to come if the water is consumed wisely. Based on data from developed countries, the basic domestic water needs do not exceed $150 \mathrm{l} / \mathrm{capita} / \mathrm{d}$, less than one third of the actual consumption rate in 2003. While we note that it is vital to supply the basic needs of water to everyone, irrespective of their income, it is vital also to charge a proper price for any amount of water consumed beyond the basic needs, to help 
curb the wasteful use of water, and its associate negative impacts on fuel reserves and on the environment. This means that subsidies should be focused and limited to average people's basic needs. Limiting quantities to basic needs help in avoiding the typical rebound effect, where gains from efficient water production may easily be offset by increasing of consumption and waste.

In the present work, the specific fuel energy consumed and the amounts of emitted $\mathrm{CO}_{2}, \mathrm{SO}_{x}$, and $\mathrm{NO}_{\mathrm{x}}$ per $\mathrm{m}^{3}$ of desalted water are calculated for fourteen different cases. Also, the amount of desalted water produced in each case for the same amount of reference fuel consumed rate (used in Case 1) is calculated.

\section{Case studies}

In view of the sometimes-subtle differences between different performance evaluation and fuel allocation methods, which can lead to very different results as mentioned above, we present our case study calculations in a very explicit way to avoid any misunderstandings.

To estimate the rate of $\mathrm{CO}_{2}$ emissions, the ratio of carbon in the fuel is assumed equal to be $0.85 \mathrm{~kg} / \mathrm{kg}$ of fuel, and burning $1 \mathrm{~kg}$ of fuel thus produces $(0.85 \times 44 / 12=) 3.1167 \mathrm{~kg}$ of $\mathrm{CO}_{2} /(\mathrm{kg}$ fuel).

Similarly the ratio of sulfur in the fuel is assumed equal to $0.012 \mathrm{~kg} / \mathrm{kg}$ of fuel, and burning $1 \mathrm{~kg}$ of fuel thus produces $(0.012 \times 64 / 32=) 0.024$ $\mathrm{kg}$ of $\mathrm{SO}_{2} /(\mathrm{kg}$ fuel $)$.

In estimating the $\mathrm{NO}_{\mathrm{x}}$ emissions, it is assumed that the plant meets the allowable emission level in the US, which is $0.258\left(\mathrm{~kg} \mathrm{NO}_{\mathrm{x}}\right) / \mathrm{GJ}$ heat output [13].

\subsection{Case 1: Fuel fired boiler driving a thermal vapor compression desalting TVC system.}

There are about 127 thermal vapor compression desalting system (TVC) units [5] having an almost 200 MIGD installed capacity in the Middle East Arab countries and Iran. These units are in general operated with steam supplied directly from fuel fired boilers, having low top brine temperature in the range of $65^{\circ} \mathrm{C}$ and using falling film horizontal tube evaporators. Most of these units were put in service in the last decade. The only reported units that use steam extracted from turbines are those in Um-Al-Nar and Al-Taweela in UAE [14]. Steam supplied to Al-Taweela units is exhausted from a backpressure turbine at 2.8 bar. In winter, when fewer turbines are in operation and available to supply steam, these desalination plants are directly supplied from the power plant's steam generator through a high pressure (HP) reducing station. Fig. 2 shows a schematic diagram of a TVC unit. It consists of multi-evaporators, steam ejector (thermal compressor TC), and end condenser. The four TVC units at Jebel Dehnna, UAE [5] shown in Fig. 2, is Case 1 of this study.

In the analysis of this Case 1, and of the following Case 2, in both of which steam is supplied to the desalting unit(s) directly from the boiler, the following are assumed:

The heat supplied to the desalting unit(s), $Q_{d}$, is equal to the boiler heat output $Q_{b}$, and is equal to the steam mass flow rate $S_{d}$ multiplied by the difference between the enthalpy at the inlet $h_{d i}$ and that at the exit $h_{d e}$, i.e.

$Q_{d}=Q_{b}=S_{d}\left(h_{d i}-h_{d e}\right)$

The gain ratio, $G R$, is defined by the ratio of the desalted water output $D$ divided by $S_{d}$

$\mathrm{GR}=\frac{D}{S_{d}}$

The fuel energy, $Q_{f d}$, supplied to the boiler to produce $Q_{b}$, and $q_{f d}$, the $Q_{f d}$ per unit desalted water, are, respectively

$Q_{f d}=Q_{b} / \eta_{b}=m_{f} \times \mathrm{LHV}$

$q_{f d}=Q_{f d} / D=Q_{b} /\left(D \eta_{b}\right)$

where $m_{f}$ is the fuel mass supply to the boiler, and LHV is the low heating value of the fuel (heat generated by the combustion of $1 \mathrm{~kg}$ of fuel, when 


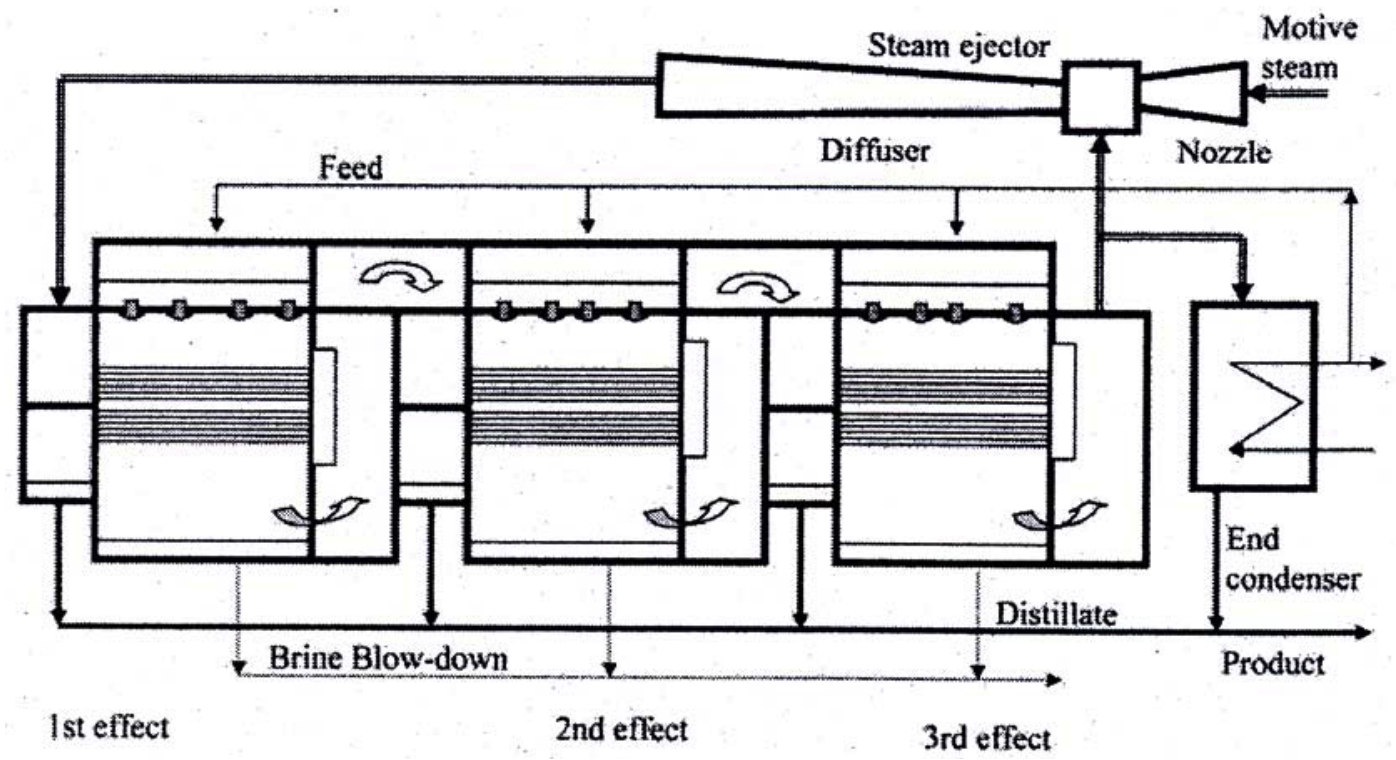

Fig. 2. Multi-effect thermal vapor compression (TVC) desalting system (Case 1).

the water in the combustion is in vapor form), and $q_{f d}$ is the specific heat per unit distillate due to heat supplied to the desalting units. LHV is considered in the following calculations equal to $40 \mathrm{MJ} / \mathrm{kg}$ fuel.

Each desalting system consumes pumping energy $W_{p}$ to move its streams, and the specific pumping energy per kg of desalted water is expressed by $W_{p} / D$. To produce the pumping energy from a power plant of thermal efficiency $\eta_{c}$, the specific fuel energy consumed to produce the pumping energy $q_{f p}=\left(W_{p} / D\right) / \eta_{c}$.

The specific fuel energy for the heat and pumping energy is thus $q_{f}=q_{f d}+q_{f p}$.

The fuel energy cost per $\mathrm{m}^{3}$ desalted water can be calculated by considering the fuel oil cost per barrel is $\$ 60 /$ barrel (or $\$ 10.52$ per GJ).

The fuel energy can be transferred to mechanical work in a power plant having efficiency $\eta_{c}$, and thus the fuel energy $Q_{f}$ has equivalent mechanical work capability $=\eta_{c} Q_{f}$.

If the specific fuel energy $Q f D$ is given in $\mathrm{MJ} / \mathrm{m}^{3}$, then the $\mathrm{CO}_{2}$ produced by producing $1 \mathrm{~m}^{3}$ of desalted water $=(Q / D) \times 3.1167 / 40(\mathrm{MJ} / \mathrm{kg}$ fuel $)$ $=0.078(Q / D) \mathrm{kg} \mathrm{CO} / \mathrm{m}^{3}$

The $\mathrm{SO}_{2}$ emitted by producing $1 \mathrm{~m}^{3}$ desalted water is thus $(Q / D) \times 0.024 / 40=0.0006(Q / D) \mathrm{kg}$ $\mathrm{SO}_{2} / \mathrm{m}^{3}$

In Case 1, the total desalted water output $D_{T}=$ $7,180 \mathrm{~m}^{3} / \mathrm{d}(314.6 \mathrm{~kg} / \mathrm{s}$ or $5.98 \mathrm{MIGD})$, and the gain ratio $\mathrm{GR}=9$.

This gives:

$S_{d}=34.956 \mathrm{~kg} / \mathrm{s}$.

$S_{d}$ is supplied to the TVC units as saturated steam of $10 \mathrm{bar}$, and enthalpy $h_{d i}=2,778.1 \mathrm{~kJ} / \mathrm{kg}$, and leaves as saturated liquid of $T=65^{\circ} \mathrm{C}$, and enthalpy $h_{d e}=272.06 \mathrm{~kJ} / \mathrm{kg}$, then:

$$
\begin{aligned}
& Q_{d}=34.956(2,778-272.06)=87,600 \mathrm{~kW} \\
& =78.6 \mathrm{MW} \\
& Q_{f d}=87.6 / 0.9=97.33 \mathrm{MW} \\
& Q_{f d} / D=q_{f d}=\frac{97,333}{314.6}=309.39 \mathrm{~kJ} / \mathrm{kg}
\end{aligned}
$$

The estimated specific pumping energy to the 
TVC, $W_{p} / D=2 \mathrm{kWh} / \mathrm{m}^{3}(7.2 \mathrm{~kJ} / \mathrm{kg})$, and $q_{f p}=7.2 /$ $0.36=20 \mathrm{~kJ} / \mathrm{kg}$.

The total specific fuel energy $\left(Q_{f} / D\right)_{T}=$ $q_{f}=20+309.4=329.4 \mathrm{~kJ} / \mathrm{kg}=329.4 \mathrm{MJ} / \mathrm{m}^{3}$, (for both heat and pumping energy added), and the total fuel energy for the specified water production rate is thus

$Q_{f}=329.4 \times 314.6 / 1000=103.626 \mathrm{MW}$.

Assuming a power plant of thermal efficiency $\eta_{c}=0.36$, the work equivalent of this $Q_{f}$ is equal to $103.626 \times 0.36=37.3 \mathrm{MW}$, and the equivalent work of the specific fuel energy $q_{f d}=Q / D$ is equal to $329.4 \times 0.36=118.8 \mathrm{~kJ} / \mathrm{g}=32.94 \mathrm{kWh} / \mathrm{m}^{3}$.

The fuel energy cost per $\mathrm{m}^{3}$ desalted water produced by this TVC, based on $\$ 60 /$ barrel (or $\$ 10.526$ per GJ $)=10.526 \times 329.4 / 1000=\$ 3.467 / \mathrm{m}^{3}$.

The $\mathrm{CO}_{2}$ production $/ \mathrm{m}^{3}=0.078 \times 329.4$

$=25.69 \mathrm{~kg} \mathrm{CO} / \mathrm{m}^{3}$.

The $\mathrm{SO}_{2}$ production $/ \mathrm{m}^{3}=0.0006 \times 329.4$

$=0.2 \mathrm{~kg} \mathrm{SO} / \mathrm{m}^{3}$

The emitted $\mathrm{NO}_{\mathrm{x}}$ is $0.3294 \times 0.258=0.094 \mathrm{~kg}$ $\mathrm{NO}_{x} / \mathrm{m}^{3}$.
The amount of fuel energy used in this Case 1 $\left(Q_{f}\right)_{T}=103.6265 \mathrm{MW}$ will be used in the rest of this paper as a reference rate of fuel energy input to compare the amount of desalted water that can be obtained from the same fuel energy input by the different studied cases.

\subsection{Case 2: Fuel fired boiler driving a multi stage flash MSF desalting system}

The multi-stage flash (MSF) is the main desalting method used in the Gulf area. Most of the existing MSF units are supplied with steam extracted from steam turbines. When no operating turbines (or no turbines at all) exist, steam is supplied directly from boiler through reducing pressure station. In the Shuwaik desalting plant in Kuwait, there are 3 MSF units operated with steam supplied directly from three fuel-fired boilers (Fig. 3), and this is considered here as Case 2.

The data given for this case are:

$D=342 \mathrm{~kg} / \mathrm{s}(6.5 \mathrm{MIGD})$

The gain ratio $\mathrm{GR}=D / S_{d}=9$.

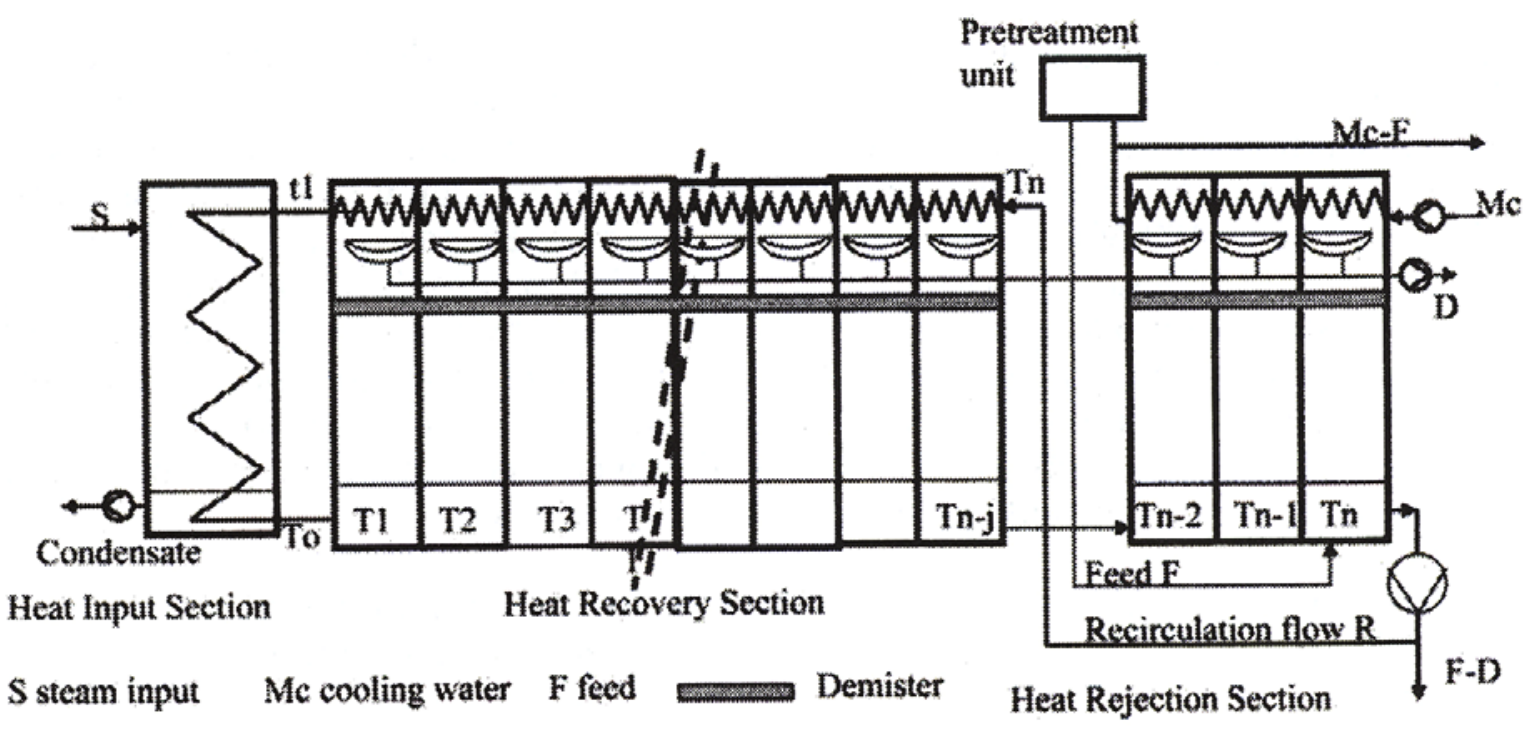

Fig. 3. Multi-stage flash MSF desalting system. 
$S_{d}=38 \mathrm{~kg} / \mathrm{s}, Q_{d}=83.7 \mathrm{MW}$

$Q_{f d}=93 \mathrm{MW}$

$Q_{f d} / D=q_{f d}=\frac{93,000}{342}=271.92 \mathrm{~kJ} / \mathrm{kg}$

The estimated specific pumping energy to the $\mathrm{MSF}=4 \mathrm{kWh} / \mathrm{m}^{3}(14.4 \mathrm{~kJ} / \mathrm{kg})$, and $q_{f p}=14.4 / 0.36=40 \mathrm{~kJ} / \mathrm{kg}$.

The total specific fuel energy $\left(Q_{f} / D\right)_{T}=q_{f}=40$ $+271.9=311.9 \mathrm{~kJ} / \mathrm{kg}=311.9 \mathrm{MJ} / \mathrm{m}^{3}$, (for both heat and pumping energy added), and the total fuel energy for the specified water production rate is thus $Q_{f}=311.9 \times 342 / 1000=106.67 \mathrm{MW}$.

The equivalent work of this $Q_{f}$ is thus $106.67 \times 0.36$ $=38.4 \mathrm{MW}$

The equivalent work of the specific fuel energy $Q_{f} / D$ is thus $311.9 \times 0.36=112.284 \mathrm{~kJ} / \mathrm{g}=$ $31.19 \mathrm{kWh} / \mathrm{m}^{3}$

The fuel energy cost per $\mathrm{m}^{3}$ desalted water produced by this MSF, based on $\$ 60 /$ barrel (or $\$ 10.526$ per GJ $)=10.526 \times 311.9 / 1000=\$ 3.283 / \mathrm{m}^{3}$
The $\mathrm{CO}_{2}$ production $/ \mathrm{m}^{3}=0.078 \times 311.9$

$=24.33 \mathrm{~kg} \mathrm{CO} / \mathrm{m}^{3}$.

The $\mathrm{SO}_{2}$ production $/ \mathrm{m}^{3}=0.0006 \times 311.9$

$=0.187 \mathrm{~kg} \mathrm{SO} / \mathrm{m}^{3}$

The emitted $\mathrm{NO}_{\mathrm{x}}=0.3119 \times 0.258$

$=0.0847 \mathrm{~kg} \mathrm{NO} / \mathrm{m}^{3}$.

When the referenced rate of fuel energy input $Q_{\text {ref }}=103.6265 \mathrm{MW}$ of Case 1 is applied to Case 2, the rate of desalted water production is $332.24 \mathrm{~kg} / \mathrm{s}$, as shown in Table 7.

Comparing Case 1 with Case 2 indicates that:

1. Although GR $=9$ for both cases, the $\left(Q_{f} / D\right)$ (heat input only) is $309.4 \mathrm{~kJ} / \mathrm{kg}$ for Case 1 , and 271.9 for Case 2. As a result, $\mathrm{PR}=8.3677$ in Case 1, and 9.52 in Case 2. This confirms that GR indeed is not a good indicator of the heat consumption by the desalters, and considering GR and PR to be the same is incorrect.

2. The specific pumping energy in Case 2 is double of that in Case 1, and this was not accounted for in ratings by PR or GR.

Table 7

Summary of the main result for the fourteen studied cases ( $\mathrm{kg}$ and $\mathrm{m}^{3}$ are of desalted water)

\begin{tabular}{|c|c|c|c|c|c|c|c|}
\hline No. & Case & $\begin{array}{l}D \text { for } Q_{\text {ref }}{ }^{*} \\
(\mathrm{~kg} / \mathrm{s})\end{array}$ & $\begin{array}{l}\left(Q_{f} / D\right)_{T} \\
\left(\mathrm{MJ} / \mathrm{m}^{3}\right)\end{array}$ & $\begin{array}{l}\mathrm{CO}_{2} \\
\left(\mathrm{~kg} / \mathrm{m}^{3}\right)\end{array}$ & $\begin{array}{l}\mathrm{SO}_{2} \\
\left(\mathrm{~g} / \mathrm{m}^{3}\right)\end{array}$ & $\begin{array}{l}\mathrm{NO}_{\mathrm{x},} \\
\left(\mathrm{g} / \mathrm{m}^{3}\right)\end{array}$ & $\begin{array}{l}\text { Fuel cost } \\
\left(\$ / \mathrm{m}^{3}\right)\end{array}$ \\
\hline 1 & Fuel fired boiler driving TVC & 314.6 & 329.4 & 25.67 & 220.4 & 94.0 & 3.47 \\
\hline 2 & Fuel fired boiler driving MSF & 332.2 & 311.9 & 24.30 & 209.0 & 80.5 & 3.28 \\
\hline 3 & Steam extracted from steam turbine driving MSF & 522.0 & 198.5 & 15.47 & 106.2 & 40.9 & 2.08 \\
\hline 4 & BPST power driving MVC and MED & 803.2 & 129.0 & 10.05 & 86.4 & 33.3 & 1.35 \\
\hline 5 & BPST power driving SWRO and MED & $1,459.9$ & 71.0 & 5.53 & 47.6 & 18.32 & 0.75 \\
\hline 6 & Steam cycle driving MVC & 863.6 & 120.0 & 9.35 & 80.4 & 31.0 & 1.26 \\
\hline 7 & Steam cycle driving SWRO & $1,727.1$ & 60.0 & 4.68 & 40.2 & 15.5 & 0.63 \\
\hline 8 & GT driving SWRO & 1,775 & 58.4 & 4.55 & 39.1 & 15.1 & 0.62 \\
\hline 9 & GT driving MVC & 887.2 & 116.8 & 9.10 & 78.3 & 31.3 & 1.23 \\
\hline 10 & GT with HRSG driving MSF and SWRO & $1,824.7$ & 56.8 & 4.43 & 38.1 & 14.6 & 0.60 \\
\hline 11 & GT/ST cycle driving SWRO & $2,514.0$ & 41.2 & 3.21 & 27.6 & 16.3 & 0.43 \\
\hline 12 & GT/ST cycle driving MVC & $1,256.0$ & 82.5 & 6.42 & 53.3 & 21.3 & 0.87 \\
\hline 13 & GT/ST cycle with BPST driving MVC and MED & $2,579.5$ & 41.9 & 3.27 & 28.1 & 10.8 & 0.44 \\
\hline 14 & GT/ST cycle with BPST driving SWRO and MSF & $2,427.0$ & 42.7 & 3.33 & 28.6 & 11.0 & 0.45 \\
\hline
\end{tabular}

${ }^{*} Q_{\text {ref }}=$ Reference fuel energy $=103.626 \mathrm{MW}$ for TVC, Case 1)

$* *$ Fuel cost based on $\$ 60 /$ barrel 
3. Fuel of high exergy was used to generate low exergy steam in fuel fired boilers for direct supply to the MSF at about 3 bar, or to TVC at 10-20 bar. This is an inefficient way of using fuel, as also demonstrated in the next Case 3.

\subsection{Case 3: Cogeneration power desalting plant (CPDP) using condensing-extraction steam tur- bine (CEST) to drive MSF desalination unit(s)}

As stated above, the use of the high exergy fuel to generate low exergy steam (as done in Cases 1 and 2) is wasteful process from the thermodynamics viewpoint. It is always better to first reduce the high exergy of the fuel through power production to the exergy level of the steam needed for desalination. This is done by first generating steam at high temperature and pressure (as required for modern steam power plants), expanding it in steam turbines to produce work, and then using the turbine extraction or exhaust steam as the heat supply to the desalting plants. A plant, where steam produces both power (work) and desalted water is known as a co-generation power desalting plant (CPDP), or dual purpose plant. The main merit of the CPDP is saving fuel as compared to two separate plants, one for water desalination and the other for power.

CPDP using steam turbines and MSF desalting units are extensively used in the Gulf area. The steam turbines are either of the condensing steam turbine (CST) or backpressure steam turbine (BPST) type. Each turbine is combined with one or more MSF units. The steam supply to the MSF unit(s) is extracted from a CST (Fig. 4) or exhausted from a BPST. Examples of some CPDP using steam turbines and MSF units in the Gulf area are given in [15]. A typical plant in Kuwait is used here as Case 3. Steam is generated at high pressure around 150 bar and temperature $538^{\circ} \mathrm{C}$. The 150 bar pressure is high enough for driving an efficient steam power plant cycle, and low enough for using natural circulation steam generators. The $538^{\circ} \mathrm{C}$ temperature is the highest al-

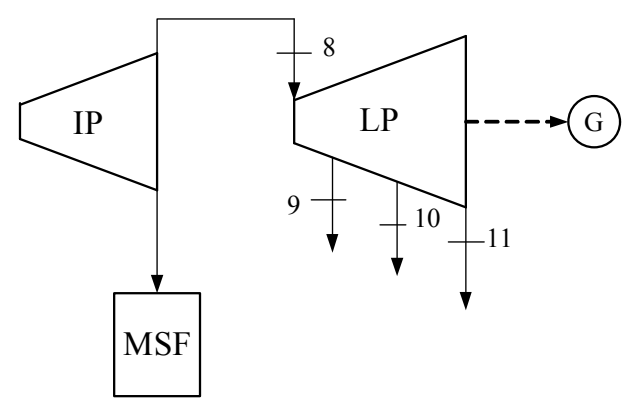

Fig. 4. Condensing-extraction steam turbine (CEST) producing power and driving a MSF desalting.

lowable for fuel oil with sulfuric content. The CPDP plant, shown in Fig. 4 uses a steam generator, a CST steam turbine, and two MSF desalting units. The use of CST in CPDP gives more operation flexibility than back pressure steam turbine. The given plant with CST can produce power at different loads from $75 \mathrm{MW}$ to $300 \mathrm{MW}$, with and without steam extracted to the MSF desalting unit. In other words, it can work as an SPP (separate power plant) producing $300 \mathrm{MW}$ down to $75 \mathrm{MW}$ electric power; or as CPDP producing $300 \mathrm{MW}$ down to $75 \mathrm{MW}$, while supplying heat of $196 \mathrm{MW}$ to two MSF desalting units.

The desalted output is $757.7 \mathrm{~kg} / \mathrm{s}$ (14.4 MIGD). The thermal energy supplied for the desalination is $196 \mathrm{MW}$, having a specific heat demand $q_{f d}=$ $\left(Q_{f} / D\right)=258 \mathrm{~kJ} /(\mathrm{kg}$ desalted water $)$.

Steam is extracted to the desalting unit(s) at rate of $77.22 \mathrm{~kg} / \mathrm{s}$ from the cross-pipe between the IP and LP (intermediate and low pressures) cylinders. If this extracted steam was expanded in the LP turbine to the condenser, instead of being extracted for desalting, it would have produce more work. This work is considered as turbine work loss due to steam extraction, and its heat equivalent is used in this study as the heat supply to the MSF units. The data for the LP turbine in the referenced plant is given in Table 8 . The mass flow rate to the LP turbine is $133.35 \mathrm{~kg} / \mathrm{s}$, its power output is $74.66 \mathrm{MW}$, and thus the specific power production is $560 \mathrm{~kW} /(\mathrm{kg} / \mathrm{s}$ steam $)$. Thus, the lost 
Table 8

Data for the LP turbine (Case 3)

\begin{tabular}{lll}
\hline Mass & $\mathrm{M}(\mathrm{kg} / \mathrm{s})$ & Enthalpy $(\mathrm{kJ} / \mathrm{kg})$ \\
\hline Mass in LP cylinder & $\mathrm{M}_{8}=133.35$ & $\mathrm{H}_{8}=2,940$ \\
Steam extracted to feed heater at point 9 & $\mathrm{M}_{9}=7.39$ & $\mathrm{H}_{9}=2,769$ \\
Steam extracted to feed heater at point 10 & $\mathrm{M}_{10}=11.13$ & $\mathrm{H}_{10}=2,608$ \\
Steam flow to condenser at point 11 & $\mathrm{M}_{11}=114.83$ & $\mathrm{H}_{11}=2,333$ \\
\hline
\end{tabular}

work due to the extraction of steam before the LP turbine $=77.22(\mathrm{~kg} / \mathrm{s}) \times 560(\mathrm{~kW} /(\mathrm{kg} / \mathrm{s})=43.234 \mathrm{MW}$.

Considering that the steam has the same enthalpy at the inlets to the LP turbine and desalters, $h_{8}=2,961 \mathrm{~kJ} / \mathrm{kg}$, and leaves the desalters as condensate at $100^{\circ} \mathrm{C}, h_{f}=419 \mathrm{~kJ} / \mathrm{kg}$, the heat supplied to the desalters $=77.22(\mathrm{~kg} / \mathrm{s}) \times(2961-419)$ $(\mathrm{kJ} / \mathrm{kg})=196.29 \mathrm{MW}$. In other words, the $77.22 \mathrm{~kg} / \mathrm{s}$ steam having the energy content of 196.29 MW, used for desalination, could have been used in the LP turbine to produce the above-calculated 43.432 MW power. By being introduced into the MSF units instead, the associated specific (per unit produced water) equivalent work is $57.06 \mathrm{~kJ} /(\mathrm{kg}$ desalted water) (i.e. $15.85 \mathrm{kWh} / \mathrm{m}^{3}$ ) and the associated specific fuel energy input $\left(Q_{f} / D\right)$, again assuming that $\eta_{p p}=0.36$, is $158.5 \mathrm{~kJ} / \mathrm{kg}$. When specific energy for pumping, $14.4 \mathrm{~kJ} / \mathrm{kg}\left(4 \mathrm{kWh} / \mathrm{m}^{3}\right)$, is added, the total specific work is $71.46 \mathrm{~kJ} /(\mathrm{kg}$ desalted water), $\left(19.85 \mathrm{kWh} / \mathrm{m}^{3}\right)$, the total specific fuel energy $\left(Q_{f} / D\right)_{T}$ becomes $198.5 \mathrm{MJ} / \mathrm{m}^{3}$. So, the rate of fuel energy used to produce 756.7 ( $\mathrm{kg}$ desalted water) $/ \mathrm{s}$ is $150.4 \mathrm{MW}$. The referenced fuel energy rate $Q_{\text {ref }}$ would produce $522.05 \mathrm{~kg} / \mathrm{s}$ (9.91 MIGD) of desalted water by this arrangement. The fuel cost is $\$ 2.085 /\left(\mathrm{m}^{3}\right.$ desalted water), based on $\$ 60 / \mathrm{bbl}$.

Based on these values, the $\mathrm{CO}_{2}$ produced is $15.47\left(\mathrm{~kg} \mathrm{CO}_{2}\right) / \mathrm{m}^{3}$.

The amount of emitted $\mathrm{SO}_{2}$ is $0.1062\left(\mathrm{~kg} \mathrm{SO}_{2}\right) /$ $\mathrm{m}^{3}$, and the emitted $\mathrm{NO}_{\mathrm{x}}$ is $0.0409\left(\mathrm{~kg} \mathrm{NO}_{\mathrm{x}}\right) / \mathrm{m}^{3}$.

The results for Case 3 are given in Table 7 . Compared with Cases 1 and 2, the Case 3 system saves more than $50 \%$ in the total specific fuel consumption $\left(Q_{f} / D\right)_{T}$. We note though that the CPDP are designed and built to produce water at an almost constant rate, while the produced power changes according to load, from $27 \%$ to full turbine rated capacity. Table 9 shows the ratios of installed, minimum, and maximum water to power demands in some Gulf countries [15]. Since the rate of water demand increase is higher than that of power demand, water plants that produces water only, or plants in which the water production is not related to the power production rate, as given in the next cases, are needed in most Gulf area.

7.4. Case 4: Water-only desalination plants using BPST power to drive both a mechanical vapor compression $M V C$ desalting plant, and, using its exhaust steam heat, a multi effect desalting MED systems (Fig. 5)

In this case, steam from a boiler is supplied to a BPST, with a discharge pressure usually higher than that of the condenser pressure of a conventional condensing turbine. The power output of

Table 9

Minimum and maximum demand, and installed, waterto-power ratio in some Gulf countries [8]

\begin{tabular}{llll}
\hline Country & $\begin{array}{l}\text { Min. } \\
\text { W/P ratio } \\
\left(\mathrm{m}^{3} / \mathrm{d}\right) / \mathrm{MW}\end{array}$ & $\begin{array}{l}\text { Max. } \\
\text { W/P ratio } \\
\left(\mathrm{m}^{3} / \mathrm{d}\right) / \mathrm{MW}\end{array}$ & $\begin{array}{l}\text { Installed } \\
\text { W/P ratio } \\
\left(\mathrm{m}^{3} / \mathrm{d}\right) / \mathrm{MW}\end{array}$ \\
\hline Kuwait & 142 & 837 & 175 \\
Bahrain & 350 & 1,580 & 570 \\
UAE & 320 & 1,170 & 347 \\
\hline
\end{tabular}




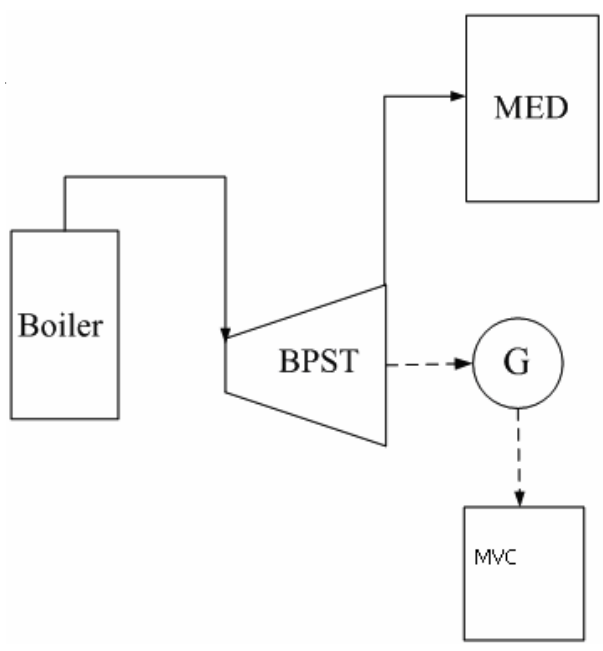

Fig. 5. Back pressure steam turbine (BPST) using its power output to drive mechanical vapor compression MVC desalting plant, and, using its exhaust steam heat to drive multi effect desalting MED systems (Case 4).

the turbine is used to drive the compressor of mechanical vapor compression MVC desalting unit either directly or through its electric power output. In addition, the steam discharged from the turbine at low pressure of $35 \mathrm{kPa}$ is supplied, as the heat source, to the first effect of a multi effect desalting MED system. This case is similar to a desalting system installed on a barge [16] using the same type of MVC and MED desalters systems but at different conditions.

As given before, the steam enters the BPST at $4 \mathrm{MPa}$ and $538^{\circ} \mathrm{C}$, and enthalpy $h_{s}=3,532.7 \mathrm{~kJ} / \mathrm{kg}$, and expands in the turbine to $35 \mathrm{kPa}$, quality of 0.95 , and enthalpy $h_{e}=2,519 \mathrm{~kJ} / \mathrm{kg}$, when it is discharged from the turbine to the MED desalting unit. The steam leaves the MED as condensate (saturated liquid at $\mathrm{P}=35 \mathrm{kPa}$, and $h_{f}=303.4$ $\mathrm{kJ} / \mathrm{kg}$ ), and is directed to the boiler through a deaerator.

For 100 MW fuel energy supplied to a boiler of $90 \%$ efficiency, the boiler heat output

$Q_{b}=90 \mathrm{MW}$, and

$$
\begin{aligned}
Q_{b} & =m_{s}\left(h_{s}-h_{f}\right)=90,000 \\
& =m_{s}(3534.2-303.4)
\end{aligned}
$$

where $m_{s}$ is the steam flow rate from the boiler, $h_{s}$ $=3532.7 \mathrm{~kJ} / \mathrm{kg}$ is the enthalpy of the steam at the boiler outlet, and $h_{f}=303.4 \mathrm{~kJ} / \mathrm{kg}$ is the feed water enthalpy to the boiler.

This gives $m_{s}=27.87 \mathrm{~kg} / \mathrm{s}$ as the boiler steam mass flow rate for that $100 \mathrm{MW}$ fuel heat input to the boiler.

If the steam leaving the boiler is supplied to a condensing turbine of $90 \%$ isentropic efficiency, and expanded to the condenser pressure at $P_{c}=$ $6.3 \mathrm{kPa}$, the steam enthalpy at the condenser inlet $h_{c}=2,333 \mathrm{~kJ} / \mathrm{kg}$, the work output, $W_{c}$, of this condensing turbine, thus is

$$
\begin{aligned}
& W_{c}=m_{s}\left(h_{s}-h_{c}\right) \\
& =27.87(3532.7-2333) / 1000=34.436 \mathrm{MW}
\end{aligned}
$$

This gives the efficiency of the condensing turbine cycle as

$\eta_{c}=\frac{W_{c}}{Q_{f}}=\frac{34.436}{100}=0.344$

In the BPST considered here and in Case 5, the steam enters the turbine at $h_{s}=3,532.7 \mathrm{~kJ} / \mathrm{kg}$, and is discharged at the conditions required by at the MED of $\mathrm{P}=0.35 \mathrm{kP}, h_{e}=2,519 \mathrm{~kJ} / \mathrm{kg}$, and its work output is thus

$$
\begin{aligned}
& W(\mathrm{BPST})=m_{s}\left(h_{s}-h_{e}\right) \\
& =27.87(3532.7-2519) / 1000=28.235 \mathrm{MW}
\end{aligned}
$$

The BPST work output driving the mechanically operated MVC is charged to the desalted water produced by the MVC system, while the work of the condensing turbine $W_{c}=34.346 \mathrm{MW}$ is charged to the two desalting systems. The heat is supplied to the MED by the steam discharged from the turbine, and this is similar to the steam extracted from the CEST to the MSF units in Case 3. The real value of this steam is its ability to produce work if it has been expanded in a turbine to the condensing pressure. This is consid- 
ered as work loss from the turbine due the extraction (or the discharge) of steam before completing its expansion to the condenser condition. This work loss (or work equivalent $W_{e}$ ) is charged to the desalted water produced by the MED in Case 4, and by the MSF in Case 3 .

This is different than the case when the steam is supplied to the desalting units directly from a boiler (as in Cases 1 and 2), in which the equivalent work was calculated simply by a multiplying the fuel energy $Q_{f}$ used to produce $Q_{d}$ (heat supplied to the desalting unit) in a boiler of efficiency $\eta_{b}$, which is equal to $Q_{f}=Q_{d} / \eta_{b}$, by a typical power cycle efficiency $\eta_{c}$. The equivalent work when the steam is supplied to the desalting units directly from the boiler system is thus $\eta_{c} Q_{f} / \eta_{b}$.

Consequently, the equivalent work to be charged to the MED unit is equal to the condensing turbine work output minus the BPST work output $=(34.436-28.235)=5.192 \mathrm{MW}$.

Based on the above, the fuel energy charged to the MVC unit is

$Q_{f}(\mathrm{MVC})=\frac{W(\mathrm{BPST})}{W_{c}} \times Q_{f}=\frac{28.235}{34.436} \times 100$

$=84.486 \mathrm{MW}$

The fuel energy charged to the MED, $Q_{f}$ $(\mathrm{MED})=100-84.486=15.532 \mathrm{MW}$

Typical specific work consumed by the MVC system is $36 \mathrm{~kJ} / \mathrm{kg}\left(10 \mathrm{kWh} / \mathrm{m}^{3}\right)$ by the compressor, and $7.2 \mathrm{~kJ} / \mathrm{kg}\left(2 \mathrm{kWh} / \mathrm{m}^{3}\right)$ by the pumps, and the specific work consumed by the $\mathrm{MVC}=36+$ $7.2=43.2 \mathrm{~kJ} / \mathrm{kg}$.

So the MVC desalted water output by the BPST work of 28.235 MW is equal to:

$$
D(\mathrm{MVC})=\frac{28,235}{(36+7.2)}=653.6 \mathrm{~kg} / \mathrm{s}
$$

and the MVC specific fuel energy $=Q_{f}(\mathrm{MVC}) / D(\mathrm{MVC})=84,486 / 653.6$ $=129.26 \mathrm{~kJ} / \mathrm{kg}$

For the MED, the performance ratio PR is usually less than, but close to, the number of effects.
A typical 6-effect plant operating in the Gulf has a performance ratio $\mathrm{PR}=5.5$.

It is noticed here again that there is a difference between the gain ratio

$$
\mathrm{GR}=\frac{\text { Distillate output }}{\text { Steam supply }}=\frac{D(\mathrm{MED})}{m_{s}}
$$

and the performance ratio PR defined by

$$
\begin{aligned}
\mathrm{PR} & =\frac{2330}{Q_{d} / D(\mathrm{MED})}=\frac{2330}{m_{s}\left(h_{e}-h_{f}\right) / D(\mathrm{MED})} \\
& =\frac{D(2330)}{m_{s}\left(h_{e}-h_{f}\right)}=\mathrm{GR} \frac{2330}{\left(h_{e}-h_{f}\right)}
\end{aligned}
$$

The heat $Q_{d}$ supplied to the MED is equal to:

$Q_{d}=m_{s}\left(h_{e}-h_{f}\right)=27.87(2519-303.4)$

$=61,757 \mathrm{~kW}$

$m_{s}$ is the steam mass flow rate to the MED (equal to that through the boiler and the turbine), and its enthalpy $h_{e}=2,519 \mathrm{~kJ} / \mathrm{kg}$, (equal to that leaving the BPST), and $h_{f}=303.4 \mathrm{~kJ} / \mathrm{kg}$ is the condensate enthalpy leaving the MED (equal to that supplied to the boiler).

For the assumed PR $=5.5$,

$$
\mathrm{GR}=\mathrm{PR} \frac{\left(h_{e}-h_{f}\right)}{2330}=\frac{(2519-303.4)}{2330}=5.23
$$

and then the MED water product $D$ (MED) $=m_{s} \times G R=27.87 \times 5.23=45.8 \mathrm{~kg} / \mathrm{s}$.

Since the equivalent work charged to the MED is $5.192 \mathrm{MW}$ due to the heat supplied to the MED, then the specific work done due to the heat supply is $Q_{d}=5192 / 145.8=35.6 \mathrm{~kJ} / \mathrm{kg}$. The specific pumping energy for the MED is $7.2 \mathrm{~kJ} / \mathrm{kg}$, and total pumping energy $=7.2 \times 145.8=1,050 \mathrm{~kW}$, and its corresponding fuel energy is $1,050 / \eta_{c}=$ $3,140 \mathrm{~kW}$. Consequently, the total specific mechanical work is $w_{e}(\mathrm{MED})=35.61+7.2$ $=42.81 \mathrm{~kJ} / \mathrm{kg}$, and the specific fuel energy for the $\mathrm{MED}=w_{e}\left(\mathrm{MED} / \eta_{c}=42.81 / 0.344=128.1 \mathrm{~kJ} / \mathrm{kg}\right.$, where $\eta_{c}$ is the condensing cycle efficiency con- 
sidered in this case. The total fuel energy for MVC and MED together, $Q_{f}(\mathrm{MEV} D+\mathrm{MVC}$ ), is 103.14 $\mathrm{MW}$, and the total MVC and MED desalted water output $D$ is $799.4 \mathrm{~kg} / \mathrm{s}$.

The total specific fuel energy

$$
\frac{Q_{f}(\mathrm{MVC}+\mathrm{MED})}{D}=q_{f}(\mathrm{MVC}+\mathrm{MED})
$$

for the output of the two systems is $129.02 \mathrm{MJ} / \mathrm{m}^{3}$.

The total specific equivalent work $w_{e}(\mathrm{MVC}+$ MED) is $43.13 \mathrm{~kJ} /$ ( $\mathrm{kg}$ desalted water) based on the above-determined cycle efficiency of 0.334 .

The fuel cost is $\$ 1.35 /\left(\mathrm{m}^{3}\right.$ desalted water), based on $\$ 60 / \mathrm{bbl}$ oil.

The $\mathrm{CO}_{2}$ emitted to the environment is 10.05 $\left(\mathrm{kg} \mathrm{CO}_{2}\right) / \mathrm{m}^{3}$,

the emitted $\mathrm{SO}_{2}$ is $0.129 \times 0.67=0.0864\left(\mathrm{~kg} \mathrm{SO}_{2}\right) / \mathrm{m}^{3}$, and the emitted $\mathrm{NO}_{\mathrm{x}}$ is $0.129 \times 0.258=$ $0.0333\left(\mathrm{~kg} \mathrm{NO}_{\mathrm{x}}\right) / \mathrm{m}^{3}$.

When the referenced fuel energy input $Q_{\text {ref }}$ $=103.6265 \mathrm{MW}$ is used, 803.3 (kg desalted water)/s (15.25 MIGD) can be produced. The results of Case 4 are given in Table 7.

\subsection{Case 5: Back pressure steam turbine BPST} driving both a seawater reverse osmosis (SWRO) and a multi-effect desalting (MED) system

The more energy-efficient SWRO desalination system can be substituted for the MVC used in Case 4, and the schematic diagram for this case is shown in Fig. 6. The SWRO is assumed to consume $6 \mathrm{kWh} / \mathrm{m}^{3}(21.6 \mathrm{~kJ} / \mathrm{kg})$. The power generation conditions of the BPST are the same as assumed and calculated in Case 4 above, and the 28.235 MW output of the BPST in Case 4 thus produces $1,307.2$ ( $\mathrm{kg}$ desalted water)/s when it drives the SWRO system. The MED produces the same $145.8 \mathrm{~kg} / \mathrm{s}$ as in Case 4 and uses $3.14 \mathrm{MW}$ fuel energy for pumping. The total fuel energy for both SWRO and MED is 103.14 MW, and their total output is 1453 ( $\mathrm{kg}$ desalted water)/s.

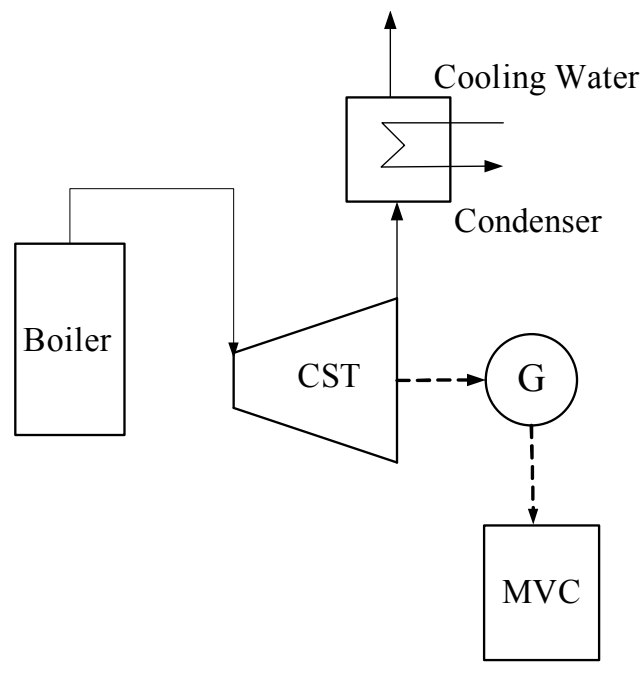

Fig. 6. Condensing steam turbine (CST) driving MVC desalting systems (Case 6).

The total specific fuel energy $\left(Q_{f} / D\right)_{T}$ for the two systems together is $70.98 \mathrm{MJ} / \mathrm{m}^{3}$.

The fuel cost is $\$ 0.75 / \mathrm{m}^{3}$, when the fuel cost is assumed equal to be $\$ 60 / \mathrm{bbl}$.

The $\mathrm{CO}_{2}$ emitted to the environment is 5.53 $(\mathrm{kg} \mathrm{CO}) / \mathrm{m}^{3}$,

the emitted $\mathrm{SO}_{2}$ is $0.071 \times 0.67=0.0476\left(\mathrm{~kg} \mathrm{SO}_{2}\right) / \mathrm{m}^{3}$, and the emitted $\mathrm{NO}_{\mathrm{x}}$ is

$0.071 \times 0.258=0.01832\left(\mathrm{~kg} \mathrm{NO}_{\mathrm{x}}\right) / \mathrm{m}^{3}$.

When the referenced fuel input $Q_{\text {ref }}$ is used, 1,459.9 ( $\mathrm{kg}$ desalted water)/s (29.7 MIGD) can be produced. The results of Case 5 are given in Table 7.

\subsection{Case 6: Steam power cycle driving a MVC} desalting system (Fig. 6)

This case is similar to Cases 4 and 5, but the backpressure steam turbine BPST is substituted by a simple condensing steam turbine CST and all the steam turbine power output is used to operate an MVC as shown in Fig. 7. For $100 \mathrm{MW}$ 


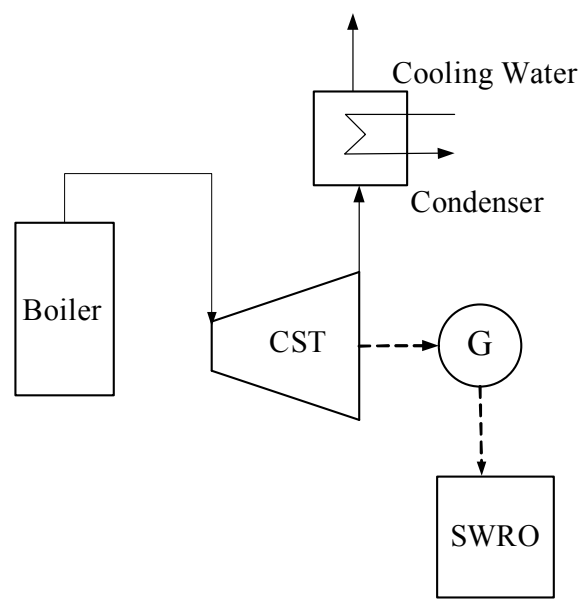

Fig. 7. Condensing steam turbine (CST) driving a SWRO desalting system (Case 7).

fuel energy input to a steam generator of a power plant of net efficiency $\eta_{c}=0.36$, the total power output is $36 \mathrm{MW}$. When all this power output is used to operate the mechanically driven MVC, the $100 \mathrm{MW}$ fuel energy is charged to the desalted water output by this desalting method. This is equivalent to power output of $36,000 \mathrm{~kW}$ ).

As given before, the MVC specific work consumption is: $10 \mathrm{kWh} / \mathrm{m}^{3}$ for the compressors, $2 \mathrm{kWh} / \mathrm{m}^{3}$ for the pumps, and thus the total specific work is $12 \mathrm{kWh} / \mathrm{m}^{3}(43.2 \mathrm{~kJ} / \mathrm{kg})$.

For $100 \mathrm{MW}$ fuel energy input to the power plant and total power output of $36 \mathrm{MW}$, the desalted water output $D(\mathrm{MVC})=36,000 / 43.2$ $=833.33(\mathrm{~kg}$ desalted water $) / \mathrm{s}$. The total specific fuel energy input $\left(Q_{f} / D\right)_{T}=100,000 / 833.33=$ $120 \mathrm{~kJ} / \mathrm{kg}$ or $\mathrm{MJ} / \mathrm{m}^{3}$.

The fuel cost based on $\$ 60 / \mathrm{bbl}$ and $5.7 \mathrm{GJ}$ heat $/ \mathrm{bbl}$ $=(60 / 5.7) \times(120 / 1000)=\$ 1.263 / \mathrm{m}^{3}$.

The $\mathrm{CO}_{2}$ emitted to the environment is $(9.35 \mathrm{~kg}$ $\left.\mathrm{CO}_{2}\right) / \mathrm{m}^{3}$,

the emitted $\mathrm{SO}_{2}$ is $0.12 \times 0.67=0.0804\left(\mathrm{~kg} \mathrm{SO}_{2}\right) / \mathrm{m}^{3}$, and

the emitted $\mathrm{NO}_{\mathrm{x}}$ is $0.12 \times 0.258=0.031\left(\mathrm{~kg} \mathrm{NO}_{\mathrm{x}}\right) / \mathrm{m}^{3}$.
The referenced fuel energy input $Q_{\text {ref }}$ can produce a distillate output of $863.6 \mathrm{~kg} / \mathrm{s}$ (16.41 MIGD). The results of Case 6 are given in Table 7 .

\subsection{Case 7: Steam power cycle driving a SWRO} desalting system (Fig. 7)

The same CST power plant used in Case 6 is used to drive a SWRO desalting system which consumes $6 \mathrm{kWh} /\left(\mathrm{m}^{3}\right.$ desalted water $),(21.6 \mathrm{~kJ} / \mathrm{kg})$ (Fig. 7). For the same100 MW fuel energy input to a steam generator of a power plant of net efficiency $\eta_{c}=0.36$, the system generator output of $36 \mathrm{MW}$ can thus desalt at the rate

$D(\mathrm{SWRO})=\frac{W}{\text { specific work }}=$

$\frac{36,000}{6\left(\mathrm{kWh} / \mathrm{m}^{3}\right)\left[(3600 \mathrm{~kJ} / \mathrm{kWh}) / 1000 \mathrm{~kg} / \mathrm{m}^{3}\right]}$

$=1666.7 \mathrm{~kg} / \mathrm{s}$

with a specific fuel heat input of

$$
\left(\frac{Q_{f}}{D}\right)_{T}=\frac{100,000 \mathrm{~kW}}{1666.7}=60 \mathrm{~kJ} / \mathrm{kg}=60 \mathrm{MJ} / \mathrm{m}^{3}
$$

The fuel cost based on $\$ 60 / \mathrm{bbl}$ and $5.7 \mathrm{GJ}$ heat $/ \mathrm{bbl}$ $=(60 \times 60) /(5.7 \times 1000)=\$ 0.6316 / \mathrm{m}^{3}$.

The $\mathrm{CO}_{2}$ emitted to the environment is $4.68(\mathrm{~kg}$ $\left.\mathrm{CO}_{2}\right) / \mathrm{m}^{3}$,

the emitted $\mathrm{SO}_{2}$ is $0.06 \times 0.67=0.0402 \mathrm{~kg} / \mathrm{m}^{3}$, and

the emitted $\mathrm{NO}_{\mathrm{x}}$ is $0.06 \times 0.258=0.0155\left(\mathrm{~kg} \mathrm{NO}_{\mathrm{x}}\right) /$ $\mathrm{m}^{3}$.

When the referenced fuel rate input $Q_{\text {ref }}$ is used, the desalted water rate becomes 1,727.1 (kg desalted water)/s (32.82 MIGD). The results of Case 7 are given in Table 7.

7.8. Case 8: Gas turbine (GT) driving a seawater reverse osmosis (SWRO) desalting syste (Fig. 8)

The following Cases 8-14 employ a reference 


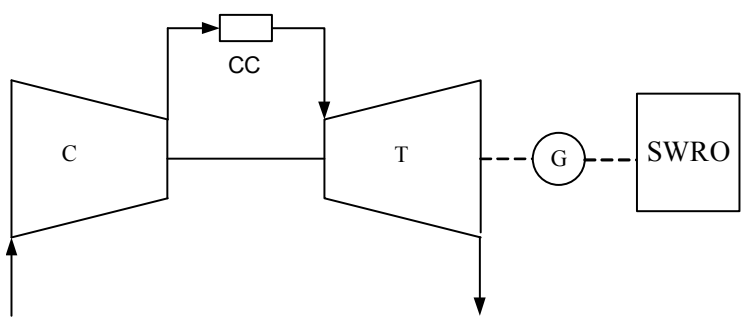

Fig. 8. Gas turbine (GT) driving a SWRO desalting system (Case 8).

gas turbine power plant [17]. Some general description of the use of GT (cf. [18]), are given here preceding the specific analyzed cases. The GT power output can be used to operate mechanically-driven desalting systems such as SWRO or MVC, while its exhaust heat gases can generate steam. This steam can be used to operate thermally-driven desalting system such as MSF, MED, or TVC, as described in the following cases. GT by themselves can be used in simple power cycles producing only power, with cycle efficiency up to about $40 \%$.

The power output of the commercially available GT-s ranges from about 0.5 to $250 \mathrm{MW}$. They were typically used by utilities for peaking capacity, and ongoing improvements in GT by raising the unit capacity, efficiency, and reliability, increasingly favor their use as base-load power generators.

Large GT-s generate electricity with low $\mathrm{NO}_{x}$ emissions, in the single digit ppm range, either with catalytic exhaust cleanup or lean pre-mixed combustion. Because of their relatively high efficiency and reliance on natural gas as the primary fuel, gas turbines emit substantially less $\mathrm{CO}_{2}$ per $\mathrm{kWh}$ generated than any other fossil fuel technologies in general commercial use. They are used extensively in industry to drive pumps, compressors, and other large mechanical equipment, and many facilities use turbines to generate electricity for use on-site. When used to generate power on-site, GT-s are often used in the CHP mode, with heat used for winter and summer air conditioning.
Combined heat and power (CHP) plants, (usually called cogeneration power desalting plant CPDP when the process heat is used by desalting units), consist of a simple cycle gas turbine combined with heat recovery steam generator HRSG (or sometimes called waste heat boiler WHB). The HRSG recovers the heat content of the hot gases leaving the GT to useful thermal energy in the form of steam. The CHP utilization factor UF, defined as the heat plus power outputs divided by the fuel energy input, or

$$
\mathrm{UF}=\frac{Q_{d}+W}{Q_{f}}
$$

can reach up to $70-80 \%$.

If high-pressure steam is generated in the HRSG of the GT, it can be used to drive a steam bottoming cycle in combined gas/steam turbine cycles (CC), thus adding the steam turbine power output to that of the GT, and producing a higher overall power output. Such gas/steam combined power cycles are the most efficient power plants, with current efficiencies up to $60 \%$, and rising.

A well-known gas turbine GE model LM6000 is used in the following Cases to show how a commercial GT can be used to operate different types of desalting system [17]. The data of the LM6000 GT are given in Table 10 for the simple and CHP GT systems.

In Case 8, the typical General Electric LM6000 GT is used to operate a SWRO desalting system. The SWRO consumes $6 \mathrm{kWh} / \mathrm{m}^{3}$ (Fig. 9). The turbine has a $40 \mathrm{MW}$ net power output, $37 \%$ efficiency, and thus its fuel input rate is $Q_{f}=108.108$ MW at the ISO conditions. The SWRO desalted water output is thus

$$
D=\frac{40,000}{(6 \times 3.6)}=1581(\mathrm{~kg} \text { desalted water }) / \mathrm{s}
$$

(35.2 MIGD), and the total specific fuel energy

$$
\left(\frac{Q_{f}}{D}\right)_{T}=\frac{108,108}{1852}=58.4 \mathrm{~kJ} / \mathrm{kg}\left(\mathrm{MJ} / \mathrm{m}^{3}\right) \text {. }
$$


Table 10

Data for the General Electric Co. LM6000 CHF gas turbines

\begin{tabular}{ll}
\hline Cost and performance characteristic & LM6000 \\
\hline Electricity generation capacity $(\mathrm{MW})$ & 40 \\
Total installed cost (year 2000 \$/kW) & $\$ 785$ \\
Electric heat rate $(\mathrm{kJ} / \mathrm{kWh}) \mathrm{HHV}$ & $9,729.72$ \\
Electrical efficiency $(\%)$ & 37 \\
Fuel input $(\mathrm{MW})$ & 108.108 \\
Required fuel gas pressure (bar) & 30 \\
\hline CHP characteristics & \\
\hline Exhaust flow $(\mathrm{kg} / \mathrm{s})$ & 120.20 \\
GT exit temperature $\left({ }^{\circ} \mathrm{C}\right)$ & 456.67 \\
HRSG exhaust temperature $\left({ }^{\circ} \mathrm{C}\right)$ & 137.78 \\
Steam output, $\mathrm{kg} / \mathrm{s}$ & 16.19 \\
Steam output, MW & 40.1 \\
Total CHP efficiency $(\%) \mathrm{HHV}$ & 74 \\
Power to heat ratio & 1.00 \\
Net heat rate $(\mathrm{kJ} / \mathrm{kWh})$ & $5,217.19$ \\
Effective electrical efficiency $(\%)$ & 69 \\
\hline
\end{tabular}

The fuel cost is $\$ 0.615 /\left(\mathrm{m}^{3}\right.$ desalted water $)$, when calculated for $\$ 60 / \mathrm{bbl}$ and $5.7 \mathrm{GJ}$ heat $/ \mathrm{bbl}$.

The emitted $\mathrm{CO}_{2}$ is $4.55\left(\mathrm{~kg} \mathrm{CO}_{2}\right) / \mathrm{m}^{3}$,

the emitted $\mathrm{SO}_{2}$ is $0.0584 \times 0.67=0.03913$ $\left(\mathrm{kg} \mathrm{SO}_{2}\right) / \mathrm{m}^{3}$, and

the emitted $\mathrm{NO}_{\mathrm{x}}$ is $0.0584 \times 0.258=0.01507$ $\left(\mathrm{kg} \mathrm{NO}_{\mathrm{x}}\right) / \mathrm{m}^{3}$.
When the referenced fuel rate input $Q_{\text {ref }}$ $=103.6265 \mathrm{MW}$ is used, the desalted water rate is

$$
\begin{aligned}
D & =\frac{103,626}{108,108} \times 35.2(\mathrm{~kg} \text { desalted water }) / \mathrm{s} \\
& =33.74 \text { MIGD } .
\end{aligned}
$$

The results of Case 8 are given in Table 7 .

\subsection{Case 9: Gas turbine GT power plant driving an MVC desalting system (Fig. 9)}

In this case, the $40 \mathrm{MW}$ power output of the LM6000 GT is used to drive an MVC desalting system, which consumes $12 \mathrm{kWh} / \mathrm{m}^{3}$ by the compressor and pumps. The rate of fuel input is 108.108 MW at the ISO conditions. So, the MVC desalted water output is

$D=\frac{40,000}{(12 \times 3.6)}=926(\mathrm{~kg}$ desalted water $) / \mathrm{s}$

\section{(17.6 MIGD)}

and the total specific fuel energy

$$
\left(\frac{Q_{f}}{D}\right)_{T}=\frac{108,108}{926}=116.8 \mathrm{~kJ} / \mathrm{kg}\left(\mathrm{MJ} / \mathrm{m}^{3}\right) .
$$

The fuel cost based on $\$ 60 / \mathrm{bbl}$ and $5.7 \mathrm{GJ}$ heat $/ \mathrm{bbl}$ $=(60 / 5.7) \times(116.8 / 1000)=\$ 1.23 / \mathrm{m}^{3}$.

The $\mathrm{CO}_{2}$ emitted to the environment is 9.1 $(\mathrm{kg} \mathrm{CO}) / \mathrm{m}^{3}$,

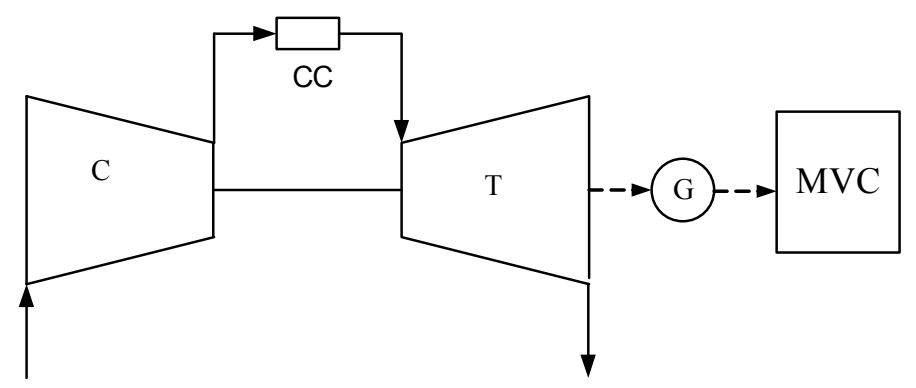

Fig. 9. Gas turbine (GT) driving a MVC desalting system (Case 9). 
the emitted $\mathrm{SO}_{2}$ is $0.1168 \times 0.67=0.0783$ $\left(\mathrm{kg} \mathrm{SO}_{2}\right) / \mathrm{m}^{3}$, and

the emitted $\mathrm{NO}_{\mathrm{x}}$ is $0.1168 \times 0.258=0.0313$ $\left(\mathrm{kg} \mathrm{NO}_{\mathrm{x}}\right) / \mathrm{m}^{3}$.

The amount of desalted water for the referenced fuel input is 887.2 ( $\mathrm{kg}$ desalted water)/s (16.87 MIGD).

The results of Case 9 are given in Table 7 .

7.10. Case 10: Gas turbine (GT) with a heat recovery steam generator (HRSG) driving both SWRO and MSF desalination plants (Fig. 10)

In this case, the GT power output is used to operate a SWRO desalting plant, and the heat of the GT exhaust gases is used to produce steam by an unfired HRSG. The steam drives an MSF desalting unit. This arrangement is used in many Gulf countries [15].

The HRSG steam output of $16.19 \mathrm{~kg} / \mathrm{s}$ can operate an MSF unit [17], which consumes 258 ( $\mathrm{kJ}$ heat $) /(\mathrm{kg}$ desalted water) as in Case 3 . The
GT power output is $40 \mathrm{MW}$. The thermal energy recovered by the generated steam from the hot gases is $Q_{d}=40.1 \mathrm{MW}$ obtained from the HRSG and supplied to the MSF units.

$Q_{d}=S\left(h_{s}-h_{f}\right)$

where $S$ is the steam flow rate to the MSF unit(s), $h_{s}$ and $h_{f}$ is the enthalpies of the steam and its condensate from the MSF unit(s), respectively. This heat produces 40,100 / 258 $=155.4$ (kg desalted water)/s by an MSF unit. The required pumping energy for the MSF unit, at $14.4 \mathrm{~kJ} /(\mathrm{kg}$ desalted water), is $14.4 \times 155.4 / 1000=2.238 \mathrm{MW}$, and this work is deducted from the $40 \mathrm{MW}$ power output of the GT. So, the net power available to drive the SWRO plant is $40-2.238=37.76 \mathrm{MW}$. The $37.76 \mathrm{MW}$ net power of the GT which can produce desalted water from the SWRO equal to:

$$
D(\mathrm{SWRO})=\frac{37,760}{(6 \times 3.6)}
$$

$=1748(\mathrm{~kg}$ desalted water $) / \mathrm{s}$.

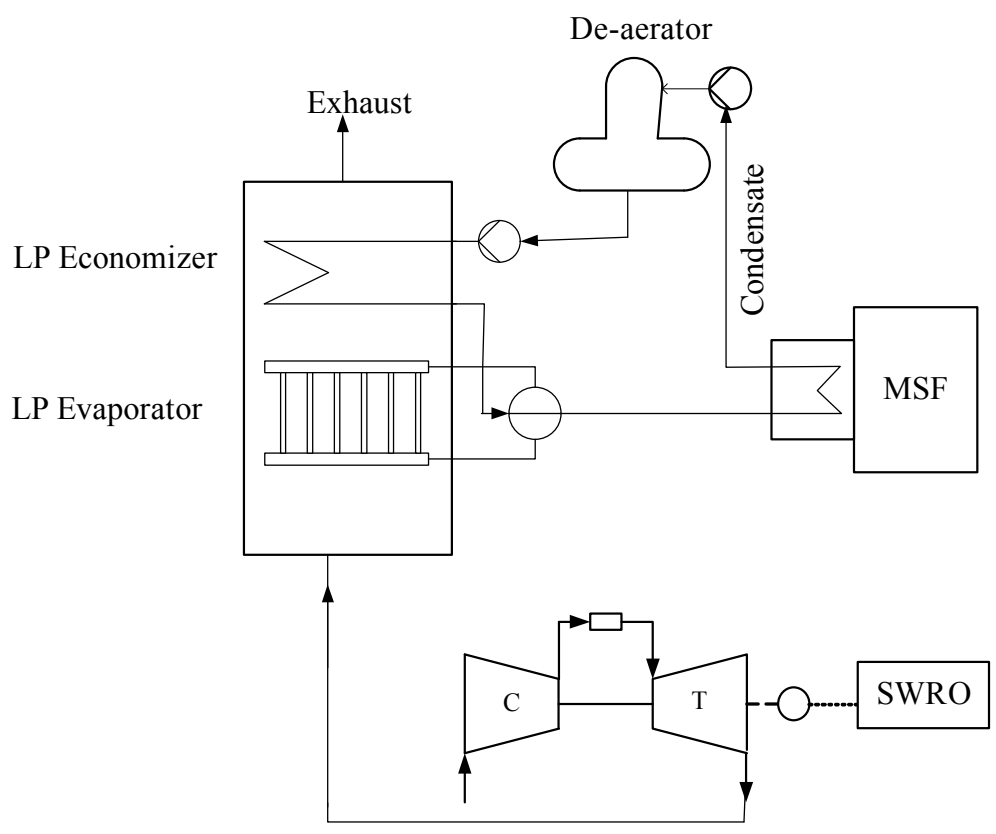

Fig. 10. Gas turbine (GT) with HRSG driving MSF and SWRO desalting systems (Case 10). 
The total desalted water output by both MSF and SWRO is $1,903.6 \mathrm{~kg} / \mathrm{s}$ (36.18 MIGD), and the total specific fuel energy

$$
\left(\frac{Q_{f}}{D}\right)_{T}=\frac{108,108}{1903.6}=56.8 \mathrm{MJ} / \mathrm{m}^{3} \text {. }
$$

The fuel cost based on $\$ 60 / \mathrm{bbl}$ and 5.7 GJ heat/ $\mathrm{bbl}=(60 / 5.7) \times(56.8 / 1000)=\$ 0.598 \mathrm{~m}^{3} / \mathrm{m}^{3}$.

The $\mathrm{CO}_{2}$ emitted to the environment is $4.425(\mathrm{~kg}$ $\left.\mathrm{CO}_{2}\right) / \mathrm{m}^{\frac{2}{3}}$,

the emitted $\mathrm{SO}_{2}$ is $0.0568 \times 0.67=0.0381\left(\mathrm{~kg} \mathrm{SO}_{2}\right) /$ $\mathrm{m}^{3}$, and the emitted $\mathrm{NO}_{\mathrm{x}}$ is $0.0568 \times 0.258=0.01465$ $(\mathrm{kg} \mathrm{NO}) / \mathrm{m}^{3}$.

When the referenced fuel rate input $Q_{\text {ref }}=$ 103.6265 MW is used, the desalted water rate becomes $(103,626 / 108,108) \times 36.18(\mathrm{~kg}$ desalted water $) / \mathrm{s}=34.616 \mathrm{MIGD}$.

The results of Case 10 are given in Table 7 .

7.11. Case 11: Combined gas/steam power cycle (CC) driving a SWRO desalting system (Fig. 11)

In this arrangement, a bottoming steam cycle, containing a HRSG, is added to the GT to form a

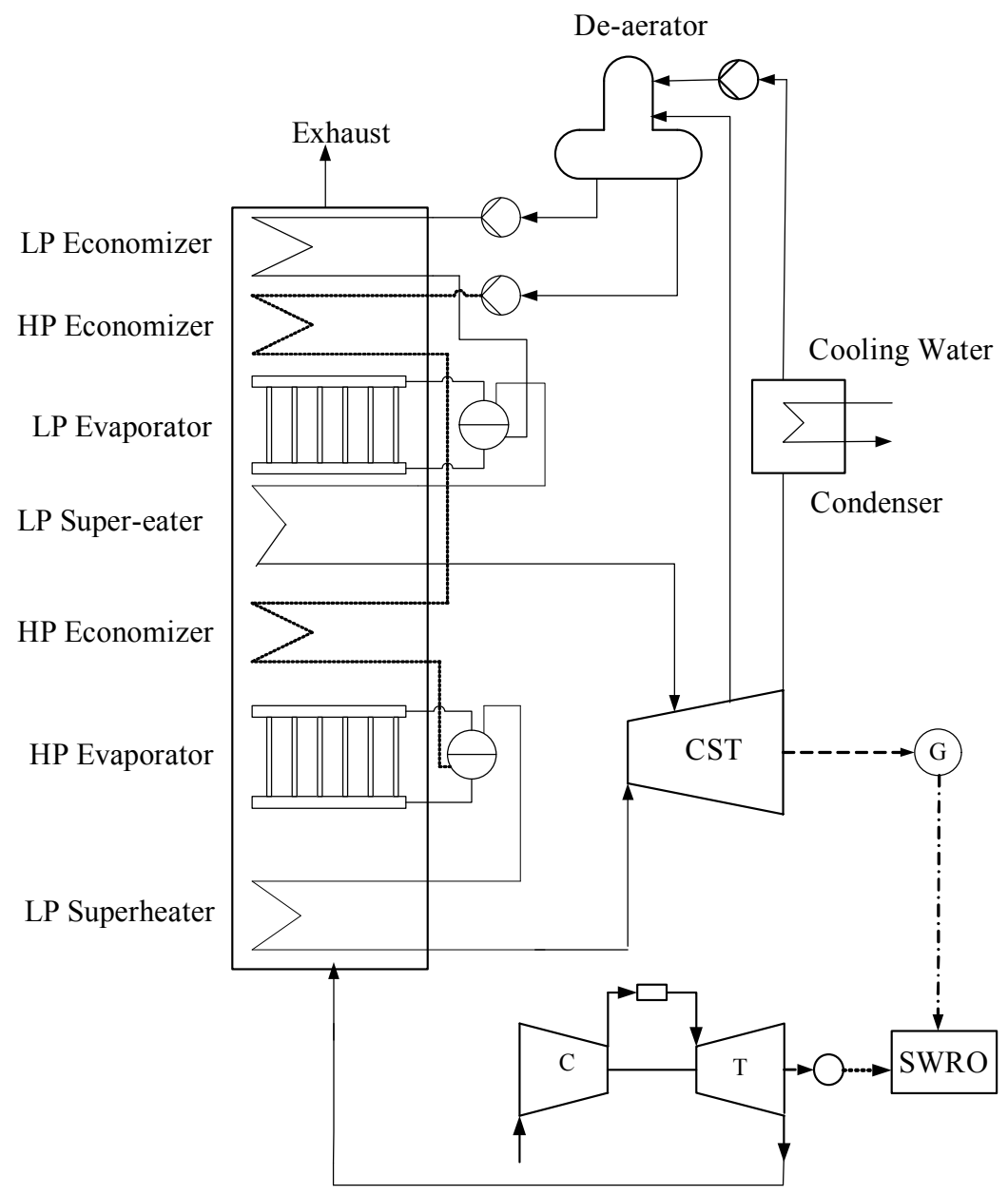

Fig. 11. Combined gas/steam power cycle (CC) driving a SWRO desalting system (Case 11). 
combined cycle. The combined cycle power output operates a reverse osmosis SWRO desalting system. The HRSG can be single or dual pressure. The pressure of the generated steam is chosen such that the steam condition at the turbine exit (at condenser inlet) has a dryness fraction (quality) $\geq 0.88$, as well as reasonable HRSG and steam cycle efficiencies. Raising the steam pressure in a single pressure HRSG increases the steam cycle efficiency, but lowers HRSG efficiency.

The use of a double pressure HRSG as shown in Fig. 12 gives sufficient thermal energy to the bottom steam turbine to produce a power output of 16.645 MW [17]. Added to the turbine's 40 MW output, the total power output thus is $56.645 \mathrm{MW}$.
When this power output operates a SWRO desalting plant, it produces $D=(56,645) /(6 \times 3.6)$ $=2622.45(\mathrm{~kg}$ desalted water $) / \mathrm{s}$ (49.84 MIGD).

The only fuel added is that to GT (i.e., 108.108 MW). Consequently, the total specific fuel input $(Q f D)_{T}=(108,108 / 2622.45)=41.2 \mathrm{MJ} / \mathrm{m}^{3}$.

The fuel cost based on $\$ 60 / \mathrm{bbl}$ and 5.7 GJ heat/ $\mathrm{bbl}=(60 / 5.7) \times(41.2 / 1000)=\$ 0.4337 / \mathrm{m}^{3}$.

The $\mathrm{CO}_{2}$ emitted to the environment is $3.21(\mathrm{~kg}$ $\left.\mathrm{CO}_{2}\right) / \mathrm{m}^{3}$,

the emitted $\mathrm{SO}_{2}$ is $0.0412 \times 0.67=0.0276$ $\left(\mathrm{kg} \mathrm{SO}_{2}\right) / \mathrm{m}^{3}$, and

the emitted $\mathrm{NO}_{\mathrm{x}}$ is $0.0412 \times 0.258=0.0163$ $(\mathrm{kg} \mathrm{NO}) / \mathrm{m}^{3}$.

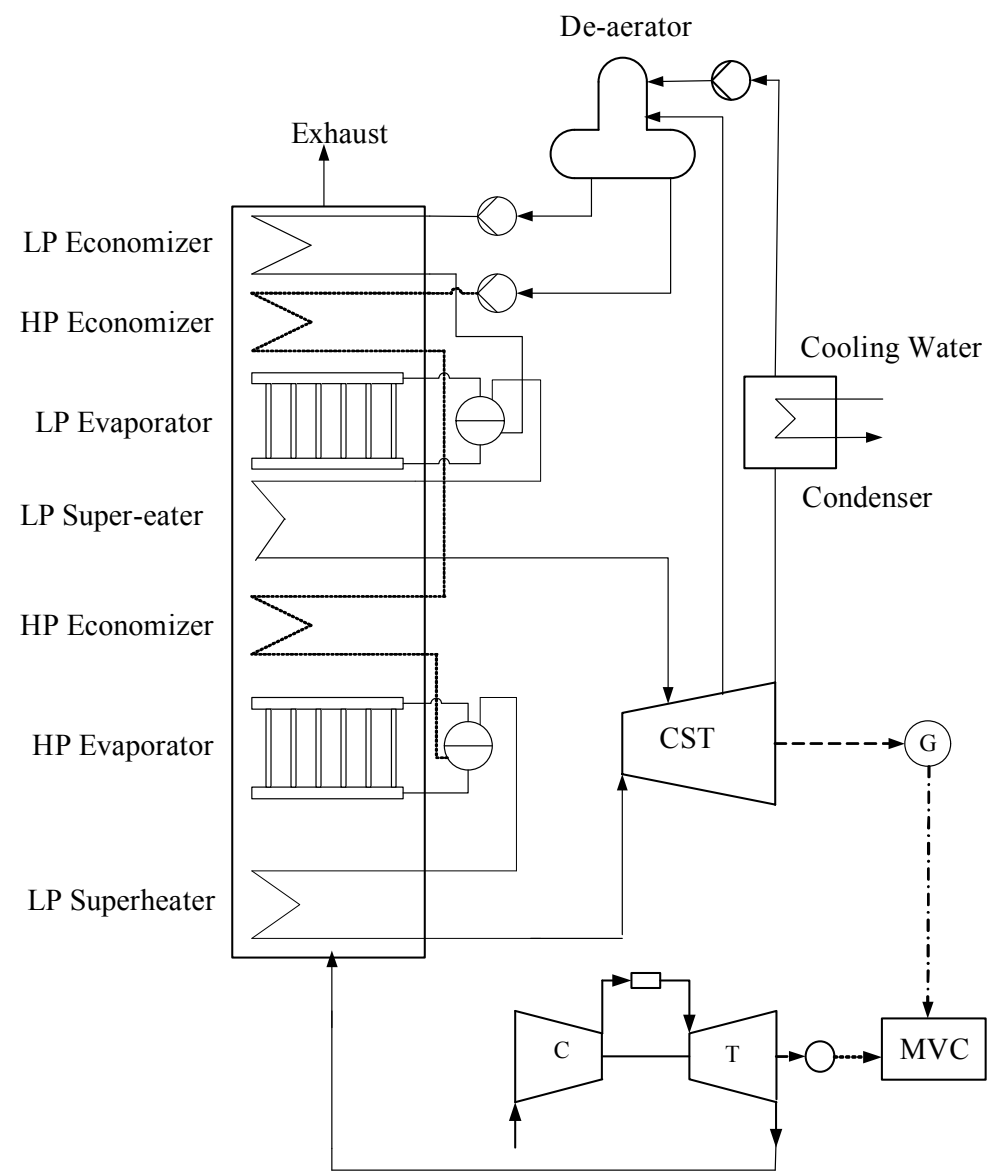

Fig. 12. Combined gas/steam power cycle (CC) driving a MVC desalting system (Case 12). 
When the referenced fuel rate input $Q_{\text {ref }}=$ 103.6265 MW is used, the desalted water rate becomes $(103,626 / 108,108) \times 49.84(\mathrm{~kg}$ desalted water $) / \mathrm{s}=47.75 \mathrm{MIGD}$.

The results of Case 11 are given in Table 7 .

\subsection{Case 12: Combined gas/steam power cycle} (CC) driving a MVC desalting system (Fig. 12)

In this arrangement, the same combined cycle of Case 11 drives a MVC desalting system. The total power output is $56.645 \mathrm{MW}$ and the desalted water output is $1,311.2(\mathrm{~kg}$ desalted water $) / \mathrm{s}$ (24.92 MIGD), based on the $12 \mathrm{kWh} /\left(\mathrm{m}^{3}\right.$ desalted water) compressor and pumping energy requirement. The fuel added to the GT is $108.108 \mathrm{MW}$ and consequently, the total specific fuel input is $82.5 \mathrm{MJ} / \mathrm{m}^{3}$.

The fuel cost based on $\$ 60 / \mathrm{bbl}$ and $5.7 \mathrm{GJ}$ heat/ $\mathrm{bbl}=(60 / 5.7) \times(82.5 / 1000)=\$ 0.868 / \mathrm{m}^{3}$.

The $\mathrm{CO}_{2}$ emitted to the environment is $6.42(\mathrm{~kg}$ $\left.\mathrm{CO}_{2}\right) / \mathrm{m}^{2}$,

the emitted $\mathrm{SO}_{2}$ is $0.0825 \times 0.67=0.0553\left(\mathrm{~kg} \mathrm{SO}_{2}\right) /$ $\mathrm{m}^{3}$, and

the emitted $\mathrm{NO}_{\mathrm{x}}$ is $0825 \times 0.258=0.0213$ $\left(\mathrm{kg} \mathrm{NO}_{\mathrm{x}} / \mathrm{m}^{3}\right.$.

When the referenced fuel rate input $Q_{\text {ref }}$ $=103.6265 \mathrm{MW}$ is used, the desalted water rate becomes $(103,626 / 108,108) \times 24.92(\mathrm{~kg}$ desalted water $) / \mathrm{s}=23.887 \mathrm{MIGD}$.

The results of this Case are given in Table 7.

7.13. Case 13: Combined gas/steam power cycle (CC) with backpressure steam turbine BPST driving both a SWRO and a MED desalting system (Fig. 13)

This case is similar to Case 12 but the steam turbine is a BPST, exhausting steam at $30 \mathrm{kPa}$ to drive a low temperature multi effect boiling MED system. The characteristics of the MED is similar to that in Case 4, namely, 6 effects, $P R=5.5$, $2 \mathrm{kWh} / \mathrm{m}^{3}$ pumping energy, brine top temperature $=60^{\circ} \mathrm{C}$, and steam supply equal to $16 \mathrm{~kg} / \mathrm{s}$. The steam turbine power output is $14.45 \mathrm{MW}$, lower than the 16.465 MW of condensing turbine Case 12 , because the steam in this case exits the turbine at $P=30 \mathrm{kPa}$ and not at the condenser pressure of $10 \mathrm{kPa}$. The MED distillate output is 88 ( $\mathrm{kg}$ desalted water)/s. The pumping power required for the MED unit is $0.634 \mathrm{MW}$. So, the net steam turbine power output after supplying the pumping energy to the MED system is $13.82 \mathrm{MW}$. The SWRO output due the power input of $40 \mathrm{MW}$ by GT and $13.82 \mathrm{MW}$ by BPST is $2,491.5 \mathrm{~kg} / \mathrm{s}$. The total desalted water production rate is 2579.5 ( $\mathrm{kg}$ desalted water)/s (49.02 MIGD).

The total specific fuel energy is $41.91 \mathrm{MJ} / \mathrm{m}^{3}$. For the referenced fuel input $Q_{\text {ref }}$, the desalted output is corrected to $2472.6 \mathrm{~kg} / \mathrm{s}$ (44.99 MIGD). It is noted here that the decrease of steam power output due to use of the backpressure steam turbine, of $2.015 \mathrm{MW}$, can be considered as the real work loss due to the use of MED desalting plant, and specific equivalent work due the heat added is $22.9 \mathrm{~kJ} / \mathrm{kg}\left(6.36 \mathrm{kWh} / \mathrm{m}^{3}\right)$, and when adding the $2 \mathrm{kWh} / \mathrm{m}^{3}$ for pumping, the total equivalent work of MED product is $8.36 \mathrm{kWh} / \mathrm{m}^{3}$.

The fuel cost based on $\$ 60 / \mathrm{bbl}$ and $5.7 \mathrm{GJ}$ heat/ $\mathrm{bbl}=(60 / 5.7) \times(41.91 / 1000)=\$ 0.4412 \mathrm{~m}^{3}$.

The $\mathrm{CO}_{2}$ emitted to environment is $3.27\left(\mathrm{~kg} \mathrm{CO}_{2}\right) /$ $\mathrm{m}^{3}$,

the emitted $\mathrm{SO}_{2}$ is $0.04191 \times 0.67=0.0281$ $\left(\mathrm{kg} \mathrm{SO}_{2}\right) / \mathrm{m}^{3}$, and

the emitted $\mathrm{NO}_{\mathrm{x}}$ is $0.04191 \times 0.258=0.0108$ $(\mathrm{kg} \mathrm{NO}) / \mathrm{m}^{3}$.

When the referenced fuel rate input $Q_{\text {ref }}$ $=103.6265 \mathrm{MW}$ is used, the desalted water rate becomes $(103,626 / 108,108) \times 49.02(\mathrm{~kg}$ desalted water $) / \mathrm{s}=46.997 \mathrm{MIGD}$.

The results of Case 13 are given in Table 7. 


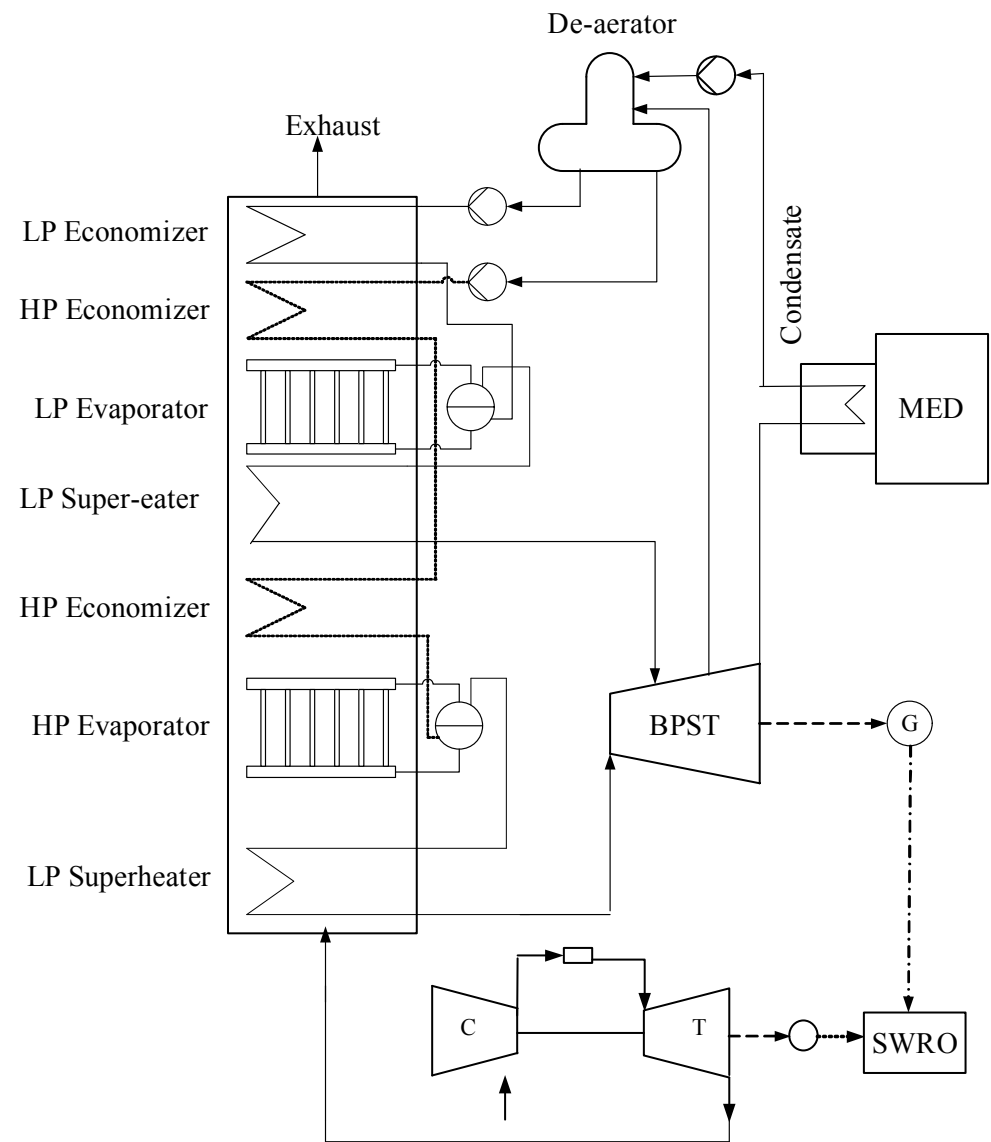

Fig. 13. Combined gas/steam power cycle (CC) with backpressure steam turbine BPST exhaust driving MED desalting, while the net power output driving SWRO system (Case. 13).

7.14. Case 14: Combined gas/steam power cycle (CC) with backpressure steam turbine (BPST) driving both SWRO and MSF desalting systems (Fig. 14)

This case is similar to the Al-Taweela plant [19], where combined gas/steam turbines cycles have bottoming backpressure steam turbines that exhaust their steam to drive multi-stage flash MSF desalting units. The plant has three gas turbines with power output equal to $228 \mathrm{MW}$ each at ISO conditions and $185 \mathrm{MW}$ at the corrected $46^{\circ} \mathrm{C}$ ambient temperature, $1190^{\circ} \mathrm{C}$ turbine inlet tem- perature (TIT), compressor pressure ratio of 16 with 17 stages, and the GT turbine has 4 stages. The GT can operate with distilled oil or natural gas.

Three HRSG-s produce $115 \mathrm{~kg} / \mathrm{s}$ steam each at 70 bar and $522^{\circ} \mathrm{C}$. Two backpressure steam turbines are used, and each has power output of $111 \mathrm{MW}$, throttling conditions (i.e. the turbine inlet condition) of $520^{\circ} \mathrm{C}, 66.5 \mathrm{bar}$, and exhaust pressure of steam supply to the MSF unit of 3.5 bar.

Four MSF desalting units are used, and each has a $12.5-M I G D(657.7 \mathrm{~kg} / \mathrm{s})$ capacity, gain ratio $(\mathrm{GR})=7.7$, specific heat consumption of 


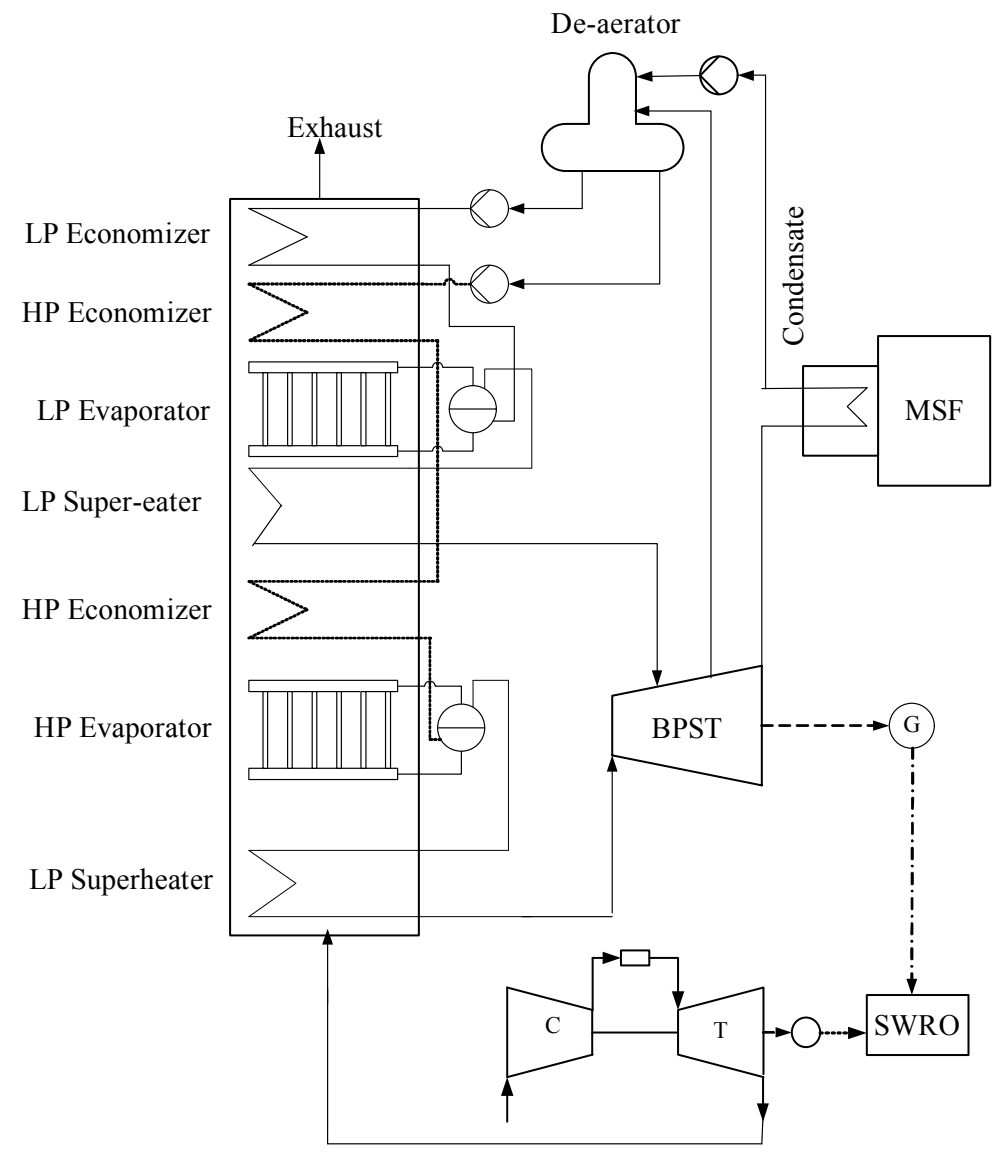

Fig. 14. Combined gas/steam power cycle (CC) with backpressure steam turbine (BPST) driving both SWRO and MSF desalting systems (Case 14).

$290 \mathrm{~kJ} /(\mathrm{kg}$ desalted water), rated top brine temperature of $110^{\circ} \mathrm{C}$, feed water salinity of 45,100 $\mathrm{mg} / \mathrm{l}$, and reported extremely low specific pumping work of $3.3 \mathrm{kWh} / \mathrm{m}^{3}$, (the typical cases in Kuwait reporting $4-4.5 \mathrm{kWh} / \mathrm{m}^{3}$ pumping energy, and it seems here that the recirculation pumps are driven directly by variable steam turbine, which consumes less energy, but not used typically at least in Kuwait.)

The plant power output from the gas turbines is $555 \mathrm{MW}$ with fuel energy input $=1,586.71 \mathrm{MW}$. The MSF units of total 50 MIGD $(2,630 \mathrm{~kg} / \mathrm{s})$ capacity consume $31.2444 \mathrm{MW}$ pumping energy. The backpressure steam turbine BPST power out- put is $222 \mathrm{MW}$. Deducting the MSF pumping work from the BPST power output, the BPST net work is $190.7556 \mathrm{MW}$. The net total power output available from the gas turbines and BPST is thus 745.7556 MW. While this power output of the Al-Taweela plant is not intended to drive a SWRO desalting plant, it is capable of producing $34,525.72(\mathrm{~kg}$ desalted water)/s from a SWRO system if it were used for that. Consequently, the total desalted water that can be obtained from this plant by MSF and SWRO desalting systems together is $37,155.72 \mathrm{~kg} / \mathrm{s}$ (706.17 MIGD), by the fuel heat input of 1,586.71 MW. This gives an overall specific fuel energy demand of $42.68 \mathrm{MJ} / \mathrm{m}^{3}$. 
Fuel cost based on $\$ 60 / \mathrm{bbl}$ and $5.7 \mathrm{GJ}$ heat $/ \mathrm{bbl}=$ $(60 / 5.7) \times(42.68 / 1000)=\$ 0.4493 / \mathrm{m}^{3}$.

The amount of $\mathrm{CO}_{2}$ emitted is $3.3\left(\mathrm{~kg} \mathrm{CO}_{2}\right) / \mathrm{m}^{3}$, the emitted $\mathrm{SO}_{2}$ is $0.0427 \times 0.67=0.02861$ $\left(\mathrm{kg} \mathrm{SO}_{2}\right) / \mathrm{m}^{3}$, and

the emitted $\mathrm{NO}_{\mathrm{x}}$ is $0.0427 \times 0.258=0.011$ $\left(\mathrm{kg} \mathrm{NO}_{\mathrm{x}}\right) / \mathrm{m}^{3}$.

When the referenced fuel rate input $Q_{\text {ref }}$ $=103.6265 \mathrm{MW}$ is used, the desalted water rate becomes $(103,626 / 1586.71) \times 706.17(\mathrm{~kg}$ desalted water $) / \mathrm{s}=46.14 \mathrm{MIGD}$.

The results of Case 14 are given in Table 7 .

\section{General comments on the energy consump- tions by desalting systems}

It is well known that:

1. The single purpose thermal desalination plants that utilize boiler raised steam directly are less efficient than dual purpose water and power plants that expand the boiler raised steam within a turbine before feeding it to the desalination plant. However single purpose desalting plant, like MSF Shuwaikh plant, is still in operation. Also other TVC units in the Gulf area and Libya are still operated with steam directly supplied directly from fuel fired boilers such as Case 1.

2. The seawater reverse osmosis SWRO desalting method is the most energy efficient desalting system. However, the only seawater desalting method used in Kuwait is the multi stage flash system MSF system (of $1.5 \mathrm{Mm}^{3} / \mathrm{d}$ total capacity), while only 30 MIGD (137× $10^{3} \mathrm{~m}^{3} / \mathrm{d}$ ) SWRO is under construction now.

3. The combined cycle gas turbine-steam turbine (GT/ST) power plant has a higher thermal efficiency than any other power plant. However, more recent power plants addition is a simple gas turbine cycle.

4. The specific energy consumptions used in this paper is not for the most efficient desalting plants. Examples are: a TVC plants are capable of utilizing motive steam with pressures as low as 2 bar and, with a suitable number of effects, can reach gain ratios (GR) of 12-14. The paper itself (page 17) reports that the Al Taweela TVC units use turbine extraction steam at 2.8 bar. The TVC fuel consumption figures in the study, however, are based on a GR of 9 and enthalpies corresponding to a motive steam supply pressure of 10 bar (page 19). Also, since as thermal plants' GRs increase their cooling water requirements and pumping energy consumptions decrease, figures of $1.2-1.5 \mathrm{kWh} / \mathrm{m}^{3}$, rather than $2 \mathrm{kWh} / \mathrm{m}^{3}$, should apply.

b MED plants, also with a suitable number of effects, as would be warranted with today's high fuel costs (that are even higher than the paper's utilized fuel cost, 90-100 US\$/barrel vs. 60 US\$/barrel) can provide GRs of 9-10 rather than 5.5, as used in the paper's calculations (a huge difference!).

c MVC plants are available today with total electrical energy consumptions of $8-9 \mathrm{kWh} /$ $\mathrm{m}^{3}$, yet the paper bases its MVC fuel consumption calculations on $12 \mathrm{kWh} / \mathrm{m}^{3}$.

d Even with the higher salinity Gulf seawater, current SWRO plants achieve specific energy consumption figures on the order of $4 \mathrm{kWh} / \mathrm{m}^{3}$, rather than the $6 \mathrm{kWh} / \mathrm{m}^{3}$ used in the study.

The results obtained strongly depend on the assumed typical desalination plant efficiencies, and we used the best current information on their values. These efficiencies are gradually improving, and in the same way that SWRO efficiency improved with the introduction of energy recovery equipment, the efficiency of distillation processes may increase significantly, by such improvements as, for one example, nano-filtration pretreatment which may more than double the current distillation top temperatures and consequently the process efficiencies. While changes 
in these efficiencies would change the results, they would not change the conclusion that higher efficiency power generation systems, such as the combined GT/ST cycles studied here, are the most desirable for efficient use of fuel.

While the current study focused on the environmental sustainability effects of the fuel use for desalination, it should be kept in mind that other important sustainability criteria for water desalination include the brine discharges from the plants. These discharges will be at temperatures higher than that of the sea, and will have concentrations of seawater salts, heavy metals, and various water treatment chemicals, that are much larger than the feed seawater. These should, of course, be studied further.

\section{Conclusions}

The paper presents series of energy and fuel consumption calculations for 14 combinations of power and desalination plants and comparing their numerical results.

The energy consumed by each desalting method was calculated based on the real fuel energy consumed to generate the thermal energy and/ or the pumping work required by the desalting units. It was shown that the present rating methods of performance ratio or the gain ratio are not suitable to take into account the pumping work and the exergy of the thermal energy supplied to the desalting units. The corresponding equivalent work of the consumed fuel energy (for both thermal and pumping work) was than calculated and used for rating each method.

The study focuses on energy use and its cost; and related emissions. It does not consider overall plant economics that would include capital and non-energy operating costs. An overall economic analysis would be necessary for choosing plants, but there are two important reasons why a focus on energy alone is of sufficient importance: (1) the future availability of fuel sources for satisfying the rapidly increasing demand, including that for fresh water, and (2) the rapidly increasing cost of fuel which makes the energy portion of the desalted water cost more dominant. In fact, other economic considerations may dilute the main purpose of this study.

It was shown how non-uniform and improper definitions of dual purpose desalination plant performance criteria and fuel/cost allocation methods could underestimate the true costs of desalted water and of the associated impact of emissions.

General comparison between all the cases considered (Table 7) indicates the following:

1. Operation of the TVC, MSF, and MED by steam directly supplied from fuel operated boilers, as cases 1 , and 2 is inefficient should be avoided.

2. The SWRO is currently the most energy efficient desalting system and all the efforts should be devoted to solve its pretreatment problems and its full applications.

3. The MVC is the most efficient distillation system, and more effort should be done towards increasing its unit capacity by developing compressors of large sizes, and decreasing its mechanical energy consumptions by raising the heat transfer coefficients in their evaporators and pre-heaters.

4. Using high efficiency combined GT/ST power production integrated with any of the considered desalination system consumes the least energy and thus incurs the lowest energy cost: the lowest of all the 14 cases considered, at $\$ 0.43 / \mathrm{m}^{3}$ is a GT/ST driving SWRO desalination (Case 11). However, GT/ST driving combined SWRO/MSF desalination systems (Case 14), or with combined MVC/MED systems (Case 13), produce an energy efficiency and water costs nearly the same as that, at $\$ 0.43$ / $\mathrm{m}^{3}$ and $\$ 0.45 / \mathrm{m}^{3}$, respectively, but with somewhat higher system complexity.

\section{Symbols}

BPST - Back pressure steam turbine

$\mathrm{CC}-$ Combined gas/steam turbine power cycles 


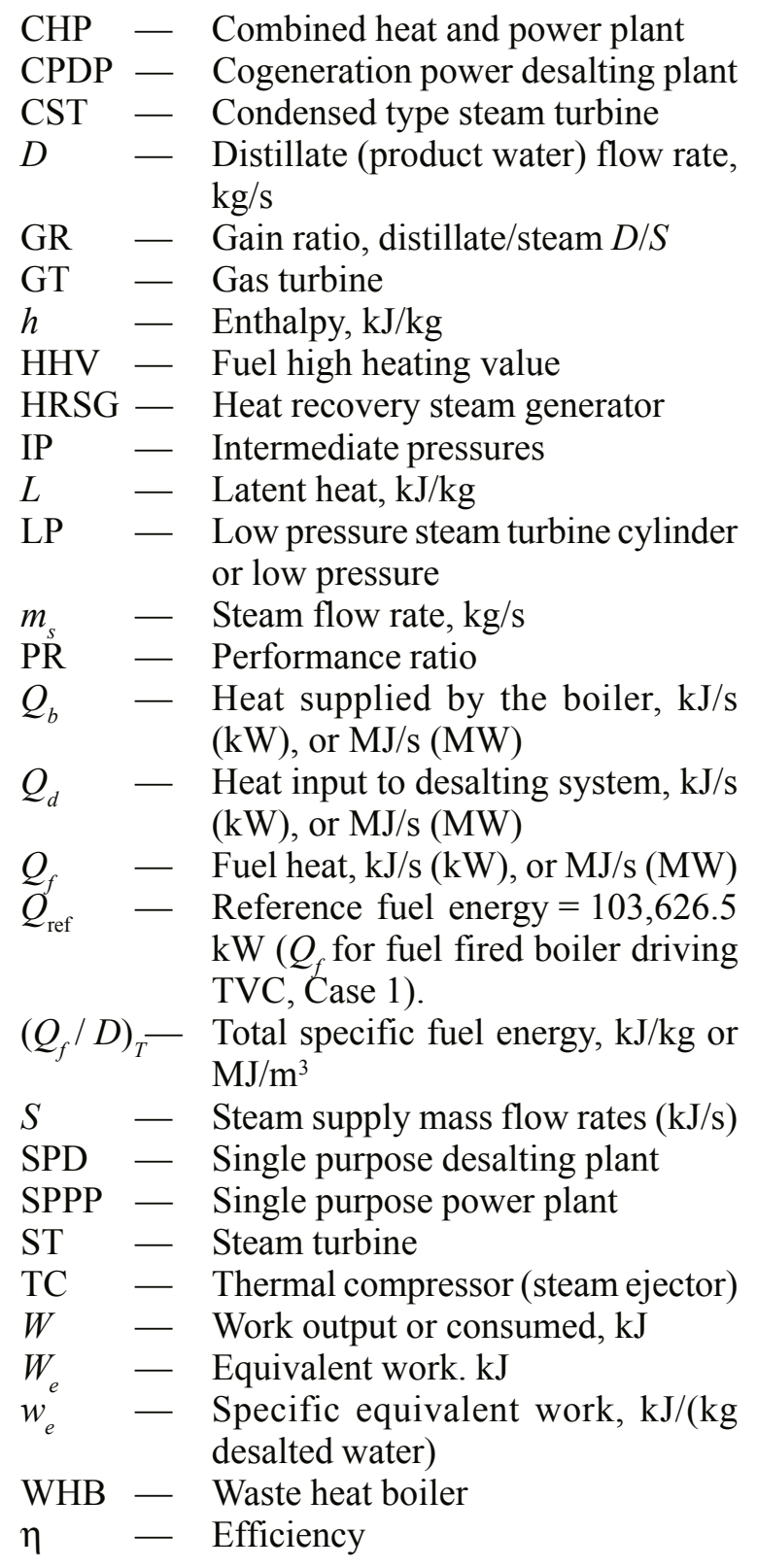

\section{Subscripts}

$\begin{array}{lll}d & - & \text { For desalting unit } \\ f & - & \text { Fuel } \\ p p & - & \text { Power plant } \\ s & - & \text { Steam } \\ T & - & \text { Total }\end{array}$

\section{References}

[1] WCED, Our Common Future: World Commission on Environment and Development, New York, Oxford University Press, 1987.

[2] H.E. Daly, Towards Steady State Economy, San Francisco, WH Freeman and Company.

[3] KISR (Kuwait Institute for Scientific Research), Geohydrological studies of Al-Wafra and AlAbdally farm areas, Vol. 1. Prepared by the Hydrology Department, Water Resources Division, Kuwait, 1994.

[4] F. Al Ruwaih and J.Almedeij, The future sustainability of water supply in Kuwait, Water Intern. J., accepted.

[5] Wangnick Consulting, 2004 IDA Worldwide Desalting Plant inventory, Report number 18, Wangnick Consulting and IDA, 2004.

[6] Kuwait Ministry of Energy, The Statistical year book, Water and Electricity, 2004, http://www.moo. gov.kw/facts/en/.

[7] C. Sommariva, H. Hogg and K. Callister, Environmental impact of seawater desalination: relations between improvement in efficiency and environmental impact, Desalination, 167 (2004) 439-444.

[8] British Petroleum, Statistical Review of World Energy 2007, http://www.bp.com/productlanding.do? categoryId=6848\&contentId=7033471 http: $/ /$ www. bp.com/productlanding.do? categoryId $=6842$ \& contentId $=7021390$.

[9] Y. Wang and N. Lior, Fuel allocation in a combined steam-injected gas turbine and thermal seawater desalination system, Desalination, 214 (2007) 306325.

[10] N. Lior and N. Zhang, Energy, exergy, and second law performance criteria, Energy, 32 (2007) 281296.

[11] N. Afgan, M. Darwish and M.G. Carvalho, Sustainability assessment of desalination plants, Desalination, 124 (1999) 19-31.

[12] K. Ringskag, International trends in water pricing and use, 5th Water Science and Technology Association (WSTA) Gulf Water Conference, Doha, Qatar, March 24-28, 2000.

[13] T.C. Koss and R.A. Jonardi, Clean air act legislation and regulated pollutants, in Standard Handbook of Power Plant Engineering, T.C. Elliot, ed., McGraw-Hill, 1989.

[14] J.W. Vermey and D. Beraud-Sudreau, Breakthrough of MED technology in very large scale applications, 
The Al-Taweela-A1 Case, Proc. IDA World Congress on Desalination and Water Reuse, Manama, Bahrain, March 2002.

[15] D. Hoffman and A. Zfati, Hybrid Desalination Systems - Effective Integration of Membrane-Thermal Desalination and Power Technology, MEDRC Project: 97-AS-008a, Middle East Desalination Research Center, Muscat, Oman.

[16] B. Ohlemann and D. Emmermann, Advanced barge mounted VTE/VC seawater desalting plant, Desalination, 45 (1983) 39-47.

[17] M.A. Darwish and N.M. Al-Najem, Co-generation power desalting plants: new outlook with gas turbines, Desalination, 161 (2004) 1-12.

[18] Environmental Protection Agency, Climate Protec- tion Partnership Division, prepared by Energy Nexus Group, Technology characterization: gas turbines, http://www.epa.gov/CHP/pdf/tech_tubines.pdf, Washington, DC, 2002.

[19] N. Wade, J. Willis and J. McSorley, Al Taweela A-2 independent water and power project, Desalination, 125 (1999) 191-202.

[20] M.A. Darwish and N. Al Najem, The water problem in Kuwait, Desalination, 177 (2005) 167-177.

[21] A.D. Kawaji, I. Kutubkhana and J.M. Wie, A 13.3 MGD seawater RO desalination plant for Yanbu Industrial City, Desalination, 203 (2007) 176-188.

[22] M.A. Darwish, Desalting fuel energy cost in view of \$75/barrel oil, Desalination, 208 (2007) 306-320. 